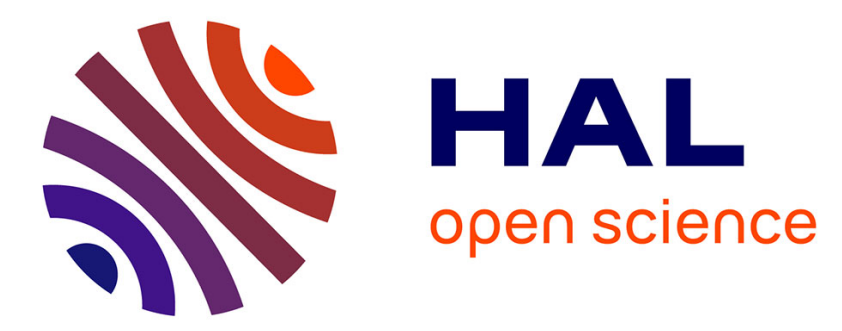

\title{
Formal asymmetries between the Romance synthetic future and conditional in the Occitan varieties of the Western Languedoc
}

\author{
Louise Esher
}

\section{- To cite this version:}

Louise Esher. Formal asymmetries between the Romance synthetic future and conditional in the Occitan varieties of the Western Languedoc. Transactions of the Philological Society, 2015, 113 (2), pp.249-270. 10.1111/1467-968X.12055 . hal-01447130

\author{
HAL Id: hal-01447130 \\ https://hal.science/hal-01447130
}

Submitted on 3 Sep 2020

HAL is a multi-disciplinary open access archive for the deposit and dissemination of scientific research documents, whether they are published or not. The documents may come from teaching and research institutions in France or abroad, or from public or private research centers.
L'archive ouverte pluridisciplinaire HAL, est destinée au dépôt et à la diffusion de documents scientifiques de niveau recherche, publiés ou non, émanant des établissements d'enseignement et de recherche français ou étrangers, des laboratoires publics ou privés. 
Preprint of: Esher, Louise. 2015. Formal asymmetries between the Romance synthetic future and conditional in the Occitan varieties of the Western Languedoc. Transactions of the Philological Society 113(2). 249-270.

\title{
FORMAL ASYMMETRIES BETWEEN THE ROMANCE SYNTHETIC FUTURE AND CONDITIONAL IN THE OCCITAN VARIETIES OF THE WESTERN LANGUEDOC
}

Louise Esher

St John's College, University of Oxford

\begin{abstract}
Most varieties of Occitan (Gallo-Romance) present a synthetic future and conditional derived from Latin periphrases CANTARE HABEO/HABEBAM 'I have/had to sing', etc. In contrast to cognate forms in other Romance languages, and the expected pattern in Occitan, the future and conditional of many varieties do not invariably share a stem. In this study, I present a typology of cases of stem asymmetry between the future and conditional recorded in a linguistic atlas survey of the western Languedoc. I argue that asymmetry initially arises through regular sound change acting differentially on the future and conditional, and is later morphologised as a novel morphomic template for paradigmatic stem distribution.
\end{abstract}

\section{KEYWORDS}

autonomous morphology; morphome; Occitan; inflectional morphology; Romance linguistics; future; conditional 
Preprint of: Esher, Louise. 2015. Formal asymmetries between the Romance synthetic future and conditional in the Occitan varieties of the Western Languedoc. Transactions of the Philological Society 113(2). 249-270.

\section{INTRODUCTION ${ }^{1}$}

Varieties of Occitan (Gallo-Romance) in the Languedoc present a synthetic future (henceforth $\mathrm{SF}^{2}$ ) and conditional (henceforth SC) which respectively derive, like their cognates in French, Spanish and Catalan, from Latin periphrases CANTARE HABEO ${ }^{3}$, etc. 'I have to sing' and CANTARE HABEBAM, etc. 'I had to sing' (see e.g. Fleischman 1982, Adams 1991, Bybee et al. 1994 for the development of these constructions). The sources of the SF and SC - infinitive followed by an auxiliary 'have' — present a transparent formal parallel, which is typically preserved, and even reinforced, in the subsequent history of the SF and SC (Maiden 2011:264) ${ }^{4}$.

Maiden (2011:264) cites a number of cases in which analogical changes affecting (or bypassing) the SF have likewise affected (or bypassed) the SC, or in which the SF and SC have jointly acquired a new, unique allomorph. Indeed, the strong formal unity of the SF and SC in Romance is highly reminiscent of that between the continuants of Latin perfective forms, which together constitute the METAMORPHOME (i.e. abstract distribution of paradigm cells, see Round in prep.) labelled 'PYTA'5 by Maiden (2005). Some examples of distinctive morphology uniquely shared by the SF and SC, illustrating the systematic identity of SF and SC stems, are given in (1) for standard Castilian.

$$
\begin{aligned}
& \text { SAPERE HABEO > sabré } \\
& \text { UALERE HABEO > valdré } \\
& \text { UENIRE HABEO > vendré }
\end{aligned}
$$

$$
\begin{aligned}
& \text { SAPERE HABEBAM > sabría } \\
& \text { UALERE HABEBAM > valdría } \\
& \text { UENIRE HABEBAM > vendría }
\end{aligned}
$$

A similarly 'symmetrical' distribution of stem forms between the SF and SC is systematically assumed by normative grammars of Occitan (e.g. Alibèrt 1976). It is presented, and indeed promoted, as the majority pattern: the extent to which identity of stem between SF and SC is taken for granted can be seen in the number of descriptive works (from individual dialect descriptions such as Sicre 1909 to the vast survey by Ronjat 1937:301-29) which give only SF forms, on the assumption that the SC has exactly the same stem

\footnotetext{
${ }^{1}$ The research reported here was conducted in part during doctoral study supported by AHRC grant 08/140462, and in part during a research fellowship at St John's College, Oxford. I am grateful to Mark Aronoff, Xavièr Bach, Chiara Cappellaro, Martin Maiden and JC Smith for much constructive discussion of this work; to the research group CLLEERSS (UMR 5263) at the University of Toulouse for permission to consult and reproduce unpublished data from the ALLOc; to my native-speaker informants for confirming the validity of these data; and to the reviewers of this article for their insightful comments. Any remaining errors are mine.

2 The terms 'SF' and 'SC' are deliberately chosen as abstract labels referring to wordforms independently of the functions associated with them.

${ }^{3}$ Vowel length in Latin etyma will only be indicated where relevant.

${ }^{4}$ Note that the present study is concerned solely with relationships of form between the SF and SC. For consideration of the extent to which the SF and SC have maintained functional parallelism, and the extent to which this may influence formal patterns, see e.g. Maiden (2011:264-66) and Esher (2013.).

${ }^{5}$ See Maiden (e.g. 2005) for the history of PYTA and examples from other Romance varieties; also $\$ 5.1$ below for the influence of PYTA on the SF and SC in Occitan. The term PYTA is deliberately chosen as an abstract label to refer to the set of paradigm cells independently of any extramorphological features.
} 
Preprint of: Esher, Louise. 2015. Formal asymmetries between the Romance synthetic future and conditional in the Occitan varieties of the Western Languedoc. Transactions of the Philological Society 113(2). 249-270.

and that it would therefore be superfluous to cite it. Yet, while there is evidence that the SF and SC in Occitan often do pattern together, and that they could therefore be considered to form a morphome (labelled 'Fuèc' by Esher 2013), the formal similarity between SF and SC is manifestly not as systematic or as strong in Occitan as in other Romance languages. Examination of linguistic atlas data shows that in many Occitan varieties, particularly within the area covered by the Atlas Linguistique du Languedoc occidental (Ravier 1978-93; henceforth ALLOc) the individual stems of the SF and SC can be distinct. Lexemes for which the stems of the SF and SC differ are said to display FORMAL ASYMMETRY between the SF and SC (Esher 2013).

The present study offers a detailed typology of cases of formal asymmetry recorded in the preparatory fieldwork notes for the ALLOc. In the majority of cases, asymmetry is found to be a consequence of regular sound change; more rarely, asymmetry can result from morphological analogy. As might be expected, some instances of asymmetry reflect transitional states in a sound change or process of analogical levelling. Other instances, and particularly the geographical correlation between different types of asymmetry, suggest that asymmetries produced by sound change can become morphologised, instantiating a new morphomic pattern which can subsequently be used as a template for analogical change. Cases of stem asymmetry between the $\mathrm{SF}$ and SC thus provide further evidence for the role of sound change in altering and initiating paradigmatic distributions.

\section{METHODOLOGY}

The data for this study were collected in the 1970s for the ALLOc, as part of the project for a Nouvel Atlas linguistique de la France par régions (see e.g. Séguy 1973 for discussion and description of this project). The fieldwork questionnaire used for the ALLOc largely replicates that developed for the Atlas linguistique et ethnographique de la Gascogne (Séguy 1954-73; henceforth ALG), and includes a substantial section on verb morphology. This section, comprising over 950 individual wordforms, consists of complete paradigms for the equivalents of French être 'be', avoir 'have', chanter 'sing', vendre 'sell', bâtir 'build', aller 'go', faire 'do', and partial paradigms ${ }^{6}$ for the equivalents of French s'asseoir 'sit', boire 'drink', connaître 'know', courir 'run', croire 'believe', croître 'grow', cuire 'cook', devoir 'have to', dire 'say', dormir 'sleep', écrire 'write', falloir 'be necessary', lire 'read', mourir 'die', naître 'be born', partir 'leave', pleuvoir 'rain', ouvrir 'open', pouvoir 'be able', recevoir 'receive', savoir 'know', sentir 'feel', servir 'serve', suivre 'follow', tenir 'hold', traire 'milk', valoir 'be worth', venir 'come', vivre 'live', voir 'see', vouloir 'want'. As the same questionnaire and methodology were used at all survey points, the ALLOc provides strictly comparable data for 132 localities across the départements Ariège (09), Aude (11), Aveyron (12), Corrèze (19), Dordogne (24), Gironde (33), Haute-Garonne (31), Lot (46), Lot-et-Garonne

\footnotetext{
${ }^{6}$ The partial paradigms comprise the infinitive, present participle, past participle, all present indicative forms, firstand third-person preterite forms, third person singular and first person plural present subjunctive forms, second person singular and plural imperatives, and third person singular forms for all other paradigm categories. Given the overwhelming tendency in the complete paradigms for all SF forms to share the stem of the SF.3SG (and likewise for all SC forms to share the stem of the SC.3SG), it is assumed that SF and SC forms not included in the partial paradigms may be straightforwardly deduced from the $3 \mathrm{SG}$ forms given.
} 
Preprint of: Esher, Louise. 2015. Formal asymmetries between the Romance synthetic future and conditional in the Occitan varieties of the Western Languedoc. Transactions of the Philological Society 113(2). 249-270.

(47), Tarn (81), and Tarn-et-Garonne (82). ${ }^{7}$ This paper follows the ALLOc convention according to which each locality is uniquely identified by a label of the form 12.34, the first two digits indicating the département and the second two indicating the individual point: thus Saint-Martin-d'Oydes (09.01) is point no. 1 within the département Ariège.

All the fieldwork interviews used the same technique, bilingual elicitation, in which the fieldworker read aloud each item on the questionnaire (in French), and the informant was asked to respond by giving the local equivalent. In total there were well over 2000 such items, and the interviews could last for several hours, sometimes with a succession of informants. The interviews were all recorded and subsequently transcribed by hand. Based on the transcriptions, four volumes of the atlas appeared, corresponding to the lexical part of the questionnaire, between 1978 and 1993. The morphological data were never published, and many of the recordings were overwritten following transcription, but the complete set of transcriptions survives to this day.

The present study is based directly on the data given in the handwritten transcriptions. The first stage of the study consisted of checking the transcriptions for any case in which, for a given lexeme in a given locality, the stem listed for the SF did not exactly match that listed for the SC. This exercise revealed few survey points without at least one instance of apparent asymmetry. The initial list was then sorted to group similar instances together, to exclude cases of purely phonetic variation, ${ }^{8}$ and to exclude hapaxes, which might be due to speech errors or transcription errors. Cases of asymmetry were only retained if they were attested in at least two locations, however widely spread. While it is highly probable that this last criterion inadvertently excludes some genuine asymmetries, this was considered preferable to including erroneous data. $^{9}$

The data retained for analysis are diverse. Some asymmetrical distributions are of phonological origin, others are cases of suppletion or heteroclisis. In some cases, innovation occurs in the SF, in others it is the SC which adopts an innovative form, and, much more rarely, both innovate but in different directions. Most types of asymmetry affect third-conjugation irregular verbs, but one particularly widespread type occurs in the productive first conjugation, which represents the majority of verbs in the lexicon. In terms of

\footnotetext{
7 The Atlas linguistique et éthnographique du Languedoc oriental (Boisgontier 1981-86; henceforth ALLOr) comprises 86 survey points across the départements Ardèche, Aude, Aveyron, Gard, Hérault, Lozère and PyrénéesOrientales. The same questionnaire is used as for the ALLOc, with the addition of a few more verbs such as plaindre and pondre. Unfortunately, the ALLOr transcriptions are less complete, and the frequent absence of the SF, SC or even both precludes an in-depth study of asymmetry in the varieties concerned.

${ }^{8}$ For instance, alternation between $/ \mathrm{s} /$ and $/ \mathrm{J} /$, which are not phonemically distinguished in these varieties. The inconsistently distributed alternation between /y/ and /œ/ in durmir 'sleep' and durbir 'open' in Ribouisse (11.03) is also likely to be a phonetic matter.

${ }^{9}$ A case in point is that of the verb sovir/seguir 'follow' in the variety of Rouairoux (81.35). The data given in the transcription appear to indicate an asymmetry due to incursive suppletion, conceivably under the influence of French suivre, with the root sov- [suß-] spread throughout the paradigm, except the SF which presents only the root seg-. (For the infinitive and past participle, the informant accepts the fieldworker's suggestion of seguir, seguit but explicitly prefers sovir, sovit; there is no indication of *sovirà for the SF). In the absence of independent confirmation, the import of these data is impossible to assess.
} 
Preprint of: Esher, Louise. 2015. Formal asymmetries between the Romance synthetic future and conditional in the Occitan varieties of the Western Languedoc. Transactions of the Philological Society 113(2). 249-270.

geographical distribution, asymmetries due to regular sound change tend to occur across a coherent area, whereas asymmetries due to morphological analogy are much less likely to do so. The following sections explore the origin and morphological status of the three major categories of asymmetry between SF and SC: those of phonological origin, those which involve heteroclisis, and those which are due to other morphological analogies.

\section{ASYMMETRIES OF PHONOLOGICAL ORIGIN}

\subsection{The 'conditionnel sans - $r$-'}

Commonly, SF and SC forms in Romance languages (including many Occitan varieties) are characterised by a stem-final -r-. However, Lanly (1971) reports that in areas of the Massif Central, the -r- of the SC has fallen, creating contrasts such as farai /fa'raj/ 'I will do' vs. $f a(r) i a ́$ /fa'jo/ 'I would do' ${ }^{10}$, and likewise Camps (1985) indicates the presence of similar forms in areas of the eastern Languedoc; Ronjat (1937:213) cites the loss of intervocalic - $r$ - in the SC as a phenomenon of rapid speech in Provence, and as an established pattern in areas of the Auvergne.

Examination of the ALLOc data shows that r-less SC forms are also frequent across the western part of the survey area, roughly corresponding to the Garonne valley and alluvial plain (Figure 1). These data clarify Alibèrt's general observation that ' $\mathrm{R}$ dels condicionals pòt s'amudir dins divèrses parlars : (dunayò, dunayòs, dunayò, etc.)' (1976:102). The ALLOc data also suggest that Allanche's (1941) unexplained convention of giving SC forms with a bracketed (r), e.g. <laura(r)ioi> 'till.SC.1SG', may be a means of representing r-less SC forms, or variation between SC forms with and without $-\mathrm{r}-.^{11}$

Most commonly, r-less SC forms are found in first-conjugation verbs (continuants of the Latin first conjugation, such as cantar 'sing', whence canta(r)iá 'sing.SC.3SG'), but they are also attested in the second conjugation (continuants of the Latin fourth conjugation, such as bastir 'build', whence basti(r)iá 'build.SC.3SG') and occasionally for third-conjugation verbs with vowel-final roots (e.g. $f a(r) i a$. 'make.SC.3SG') . It is much rarer to find r-less SC forms in regular third-conjugation verbs (continuants of the Latin third conjugation, e.g. batre 'beat', whence bat(r)iá 'beat.SC.3SG'), other than in varieties in which the majority third-conjugation pattern is for SF and SC to present a theme vowel /e/, hence bate(r)iá 'beat.SC.3SG'. These data indicate that the distribution of SC forms is not directly determined by conjugational class membership, but that $\mathrm{r}$-less SC forms tend to arise where the original form presented a sequence $\mathrm{V}^{\prime} \mathrm{rj} \mathrm{V}$.

\footnotetext{
${ }^{10}$ Standard Occitan orthography systematically includes a $<\mathrm{r}>$ in the SC, which obscures the presence of r-less SC forms. I cite such forms in standard orthography with the grapheme $<r>$ in parentheses. An equivalent convention will be applied below for those varieties which have undergone deletion of intervocalic $/ \mathrm{g} /$.

${ }^{11}$ It is curious that reference to r-less SC forms is so rare in grammars for the western Languedoc area, since such forms are attested around Toulouse from at least the eighteenth century, eg. < debignayots $>$ 'guess.SC.2PL', from the transcript of a speech by Sermet (1732-1808) cited in Eygun (1999:440). Among the only descriptions to acknowledge these forms explicitly for a given variety is Kelly (1973).
} 
Preprint of: Esher, Louise. 2015. Formal asymmetries between the Romance synthetic future and conditional in the Occitan varieties of the Western Languedoc. Transactions of the Philological Society 113(2). 249-270.

The much wider geographical distribution of first-conjugation r-less SC forms indicates that such forms probably originated in a sound change $\mathrm{a}^{\prime} \mathrm{rj \textrm {V }}>\mathrm{a}^{\prime} \mathrm{jV}$, which is now defunct in most varieties. Variation between first-conjugation SC forms with and without -r- is still attested at some survey points, such as Gaillac (81.05) where the first of two informants initially gives a series of r-less SC forms (/kanta'jo/ 'sing.SC.1SG', etc.), but then, in careful pronunciation, produces a series of forms with -r- (/kanta' rjo/, etc.), while the second informant only gives forms with -r-. Such real-time variation is, however, much commoner for the second conjugation.

Commonly, r-deletion in the first conjugation propagates, as a lexically diffuse change, into lexemes of other conjugational classes, typically the second conjugation, and some third-conjugation lexemes which present the same VrjV context. (In the far south of the survey area, regular third conjugation verbs are more likely to undergo deletion of yod than of -r-, giving SC forms such as batr(i)á 'I would beat').

The deletion of -r- is, however, confined to verbs. Examination of ALLOc maps 440 'pigsty' and 777 'sawmill' (nouns potentially presenting the context V' ${ }^{\prime} \mathrm{V}$, e.g. porcariá, resegariá respectively), for the varieties in which first- and second-conjugation SC forms are systematically r-less, finds no forms in which -r- has fallen, although the derivational suffix -ariá is phonologically identical to the sequence originally found in first-conjugation SC forms. While several areas use etymologically unrelated expressions (e.g. rua 'street', estable dels pòrcs 'pigsty'), the ALLOc data give no evidence for forms such as */purka'jo/ or */resega'jo/ in place of /purka' rjo/ and /resega' rjo/. ${ }^{1213}$

It is also significant that this study found no cases in which the SF forms of a lexeme had been analogically remodelled on the corresponding r-less SC forms: r-deletion in the SC, causing asymmetry, is neither resisted nor repaired.

Within the verb morphology of the many varieties affected, the r-less SC forms thus constitute an initial precedent for stem asymmetry between the SF and SC. This precedent is potentially significant for two reasons. Firstly, it is well established that regular sound change, creating novel patterns of allomorphy, is a major source of new morphomic distributions in the history of Romance languages, including Occitan (see e.g. Maiden 2009a, 2011). Secondly, as Albright (2009) demonstrates, the forms which serve as models for analogical change tend to be those with high type frequency within the lexicon; as discussed above, $r$ -

\footnotetext{
${ }^{12}$ I am grateful to my informant Philippe Tournier for data confirming the contrast between nouns in -ariá -/a'rjə/ and verbs in -ariá -/a'jo/ in the area of Toulouse.

13 An interesting comparison with these data is afforded by Maiden's (1991) survey of metaphony in Italo-Romance, which finds that metaphony in verbs can affect a wider range of vowels than metaphony in the noun/adjective, and that the degree of assimilation undergone by vowels subject to metaphony can be greater in verbs than in the noun/adjective. Maiden argues that verbs in Romance characteristically have a more 'diffuse' paradigm than other word classes, marking a greater range of morphosyntactic properties and displaying a greater degree of stem allomorphy, and that ' $\mathrm{t}]$ he stem changes introduced by incipient sound change are therefore more readily tolerated in the verb than elsewhere' (1991:239). An equivalent analysis can be made for the deletion of -r- in the Occitan SC forms discussed here: a nascent sound change is tolerated and generalised in the 'diffuse' verb paradigm, where its output subsequently becomes morphologised, but the same novel change is resisted in other word classes, in which stem allomorphy is much less extensive.
} 
Preprint of: Esher, Louise. 2015. Formal asymmetries between the Romance synthetic future and conditional in the Occitan varieties of the Western Languedoc. Transactions of the Philological Society 113(2). 249-270.

deletion in Occitan SC forms applies initially to the conjugation with the highest type frequency of all. Since r-deletion by regular sound change introduces a novel pattern of stem allomorphy with high type frequency, it is plausible that speakers, generalising across all the affected lexemes, might deduce a novel morphomic template for stem distribution within a paradigm, and subsequently extend this new template, which more sharply differentiates the SF from the SC, to further lexemes.

\subsection{Vocalic asymmetry by monophthongisation}

Another widespread type of asymmetry, though one of much lower type frequency in any given variety, results from differential monophthongisation of an etymological diphthong. The lexemes affected are those in which a velar or dental obstruent in coda position within the Fuèc stem has vocalised to $/ \mathrm{j} /$, which creates a diphthong with the preceding vowel. ${ }^{14}$ For example, veire 'see' usually has SF forms such as veirà / $\beta \mathrm{ej}$ 'ra/ 'see.SF.3SG', which are the regular outcome of UIDERE HABET, etc. via syncope of atonic vowels, lowering of I to /e/, and vocalisation of D. The SC forms are predicted to undergo exactly the same changes, producing commonly attested forms such as veiriá / $\beta$ ej' rjo/ 'see.SC.3SG'. Sporadically, however, the final vowel of the SC stem undergoes monophthongisation, replacing/uj/ and /ej/ with /u/ and /e/, while the etymological diphthong is preserved in the SF. Examples of this pattern are given in Table $1 .^{15}$

\footnotetext{
14 Several lexemes in the ALLOc survey present vocalisation of labial obstruents to /w/, but this study found no watertight attestation of equivalent vocalic asymmetry for these verbs. For Lauzerte (82.02), the transcription gives escrirà /ehkri'ra/ or escriurà /ehkriw'ra/ 'write.SF.3SG' vs. escriurá /ehkriw'ro/ 'write.SC.3SG', but it is striking that here the direction of monophthongisation is reversed, a phenomenon otherwise encountered only at Le Bastit (46.15) for the single lexeme 'believe': crerà /kre'ra/ 'believe.SF.3SG' vs. creiriá /krej'rjo/ 'believe.SC.3SG'. If these isolated examples are genuine, they represent a separate development.

${ }^{15}$ For reference, a sample infinitive form is provided for each lexeme. The infinitive is itself subject to extensive regional variation, but such variation is independent of that observed for the SF and SC forms (see eg. Bach \& Esher forthcoming for the formal dissociation of the infinitive from other members of the paradigm, including the SF and SC). In Tables 1-12, which focus on SF/SC form pairings across diverse localities and independently of other wordforms, a single infinitive form is given, following the standard proposed in Alibèrt's (1976) grammar. In Tables 13-17, which reproduce partial paradigms for individual localities, the infinitive forms given are those in the ALLOc transcriptions.
} 
Preprint of: Esher, Louise. 2015. Formal asymmetries between the Romance synthetic future and conditional in the Occitan varieties of the Western Languedoc. Transactions of the Philological Society 113(2). 249-270.

\begin{tabular}{|c|c|c|c|}
\hline lexeme & SF.3SG & SC.3SG & localities in which attested \\
\hline $\begin{array}{l}\text { cóser } \\
\text { 'cook' }\end{array}$ & coirà /kuj'ra/ & coriá /ku'rjo/ & $\begin{array}{l}81.12,81.23,81.32,81.34,81.35,46.23,82.13 \text {, } \\
46.24\end{array}$ \\
\hline $\begin{array}{l}\text { conéisser } \\
\text { 'know' }\end{array}$ & coneirà /kunej'sa/ & coneriá /kune' rjo/ & $09.30,81.12,81.30,81.34$ \\
\hline $\begin{array}{l}\text { creire } \\
\text { 'believe' }\end{array}$ & creirà /krej'ra/ & creriá/kre' cjo/ & $\begin{array}{l}46.11,81.06,81.07,81.12,81.21,81.22,81.32, \\
81.34,81.35,24.13\end{array}$ \\
\hline $\begin{array}{l}\text { poder } \\
\text { 'be able' }\end{array}$ & poirà /puj'ra/ & poriá /pu'rjo/ & $\begin{array}{l}\text { 11.21, 31.11, 46.02, 46.11, 81.03, 81.06, 81.07, } \\
\text { 81.12, 81.21, 81.22, 81.23, 81.30, 81.34, 81.35, } \\
82.10,82.11,47.11,46.23,46.25,82.13,24.12, \\
24.33,24.13\end{array}$ \\
\hline $\begin{array}{l}\text { veire } \\
\text { 'see' }\end{array}$ & veirà /ßej'ra/ & veriá/ße' сjə/ & $\begin{array}{l}\text { 46.11, 46.14, 81.04, 81.06, 81.07, 81.12, 81.21, } \\
\text { 81.22, 81.23, 81.31, 81.32, 81.34, 81.35, 46.23, } \\
\text { 47.11, 47.12, 46.25, 82.20, 82.13, 24.13, 24.15, } \\
24.30,47.10\end{array}$ \\
\hline
\end{tabular}

Table 1. Vocalic asymmetry by monophthongisation.

Asymmetry of this vocalic type is robustly attested within the area presenting r-less SC forms, and examples of SC forms illustrating both types of asymmetry are given in Table 2. Although the $\mathrm{Vj}$ sequence resulting from loss of -r- and monophthongisation superficially resembles the etymological diphthong, the marginal presence of monophthongal forms with -r- at Douzains (47.02) and Montayral (47.14) argues for the resemblance being coincidental. 
Preprint of: Esher, Louise. 2015. Formal asymmetries between the Romance synthetic future and conditional in the Occitan varieties of the Western Languedoc. Transactions of the Philological Society 113(2). 249-270.

\begin{tabular}{|c|c|c|c|}
\hline lexeme & SF.3SG & SC.3SG & localities \\
\hline \multirow{3}{*}{$\begin{array}{l}\text { cóser } \\
\text { 'cook' }\end{array}$} & coirà /kuj'ra/ & $c o(r) i a ́ / \mathrm{ku}^{\mathrm{j} j \jmath /}$ & $33.11,24.02,24.22,24.03$ \\
\hline & coirà & $\begin{array}{l}\text { co(r)iá } \\
\text { coriá } / \mathrm{ku} \text { 'rjo/ }\end{array}$ & 47.02 \\
\hline & queirà /kej'ra/ & que(r)iá/ke'jə/ & $47.05,47.03,24.01$ \\
\hline $\begin{array}{l}\text { conéisser } \\
\text { 'know' }\end{array}$ & coneirà /kunej'ra/ & cone(r)iá/kune'jo/ & 24.21 \\
\hline \multirow[t]{2}{*}{$\begin{array}{l}\text { creire } \\
\text { 'believe' }\end{array}$} & creirà /krej'ra/ & cre(r)iá/kre'jo/ & $\begin{array}{l}11.02,31.01,31.12,47.12,47.14,33.11 \text {, } \\
47.21,82.21\end{array}$ \\
\hline & creirà /krej' ro/ & cre(r)iá/kre'jo/ & $\begin{array}{l}24.10,24.12,47.10,47.05,47.02,24.02 \\
24.21,24.03,24.22,24.20,24.14,47.03\end{array}$ \\
\hline $\begin{array}{l}\text { poder } \\
\text { 'be able' }\end{array}$ & poirà /puj'ra/ & po(r)iá/pu'jə/ & $31.10,47.31,82.21,24.31$ \\
\hline \multirow{4}{*}{$\begin{array}{l}\text { veire } \\
\text { 'see' }\end{array}$} & veirà /ßej'ra/ & $v e(r) i a ́$ / $\beta \mathrm{e}$ jo/ & $31.10,31.11,33.11,24.01,47.31,82.21$ \\
\hline & veirà / $\beta$ ej' го/ & $v e(r) i a ́$ & $\begin{array}{l}24.10,24.02,24.20,24.03,47.05,24.21, \\
24.22,24.12,47.02,47.03\end{array}$ \\
\hline & veirà & $\begin{array}{l}\text { ve(r)iá } \\
\left.\text { (veriá } / \beta \mathrm{e}^{\prime} \mathrm{rj} \mathrm{s} / 4^{\text {th }} \text { time }\right)\end{array}$ & 47.14 \\
\hline & veirà & $v i(r) i a ́ / \beta i ' j \jmath /$ & 11.04 \\
\hline
\end{tabular}

Table 2. Vocalic asymmetry and r-less SC.

A much rarer variant, in which /ej/ is replaced by /i/, is found in three localities (Table 3).

\begin{tabular}{|c|c|c|c|}
\hline lexeme & SF.3SG & SC. $3 \mathrm{SG}$ & localities \\
\hline $\begin{array}{l}\text { creire } \\
\text { 'believe' }\end{array}$ & creirà /krej' ro/ & cririá/kri' cjə/ & 46.20 \\
\hline veire & veirà /bej' 'э/ & viriá /bi 'rjo/ & 46.21 \\
\hline 'see' & veirà / $\beta$ ej'ra/ & $\begin{array}{l}\text { veiriá / } \beta \text { ej'rjo/ } \\
\text { viriá / } \beta \mathrm{i}^{\prime} \text { ' } \mathrm{s} / /\end{array}$ & 09.11 \\
\hline
\end{tabular}

Table 3. Vocalic asymmetry (variant).

A significant difference between the vocalic type of asymmetry and the r-less SC forms is that asymmetry via monophthongisation can be, and sometimes is, 'repaired' by introducing the monophthong into the SF. SF forms with monophthongs are attested at several survey points, and two points appear to indicate change in progress in this direction (Table 4). Such change is, however, relatively rare. It is also interesting to note that at neither Toulouse (31.12) nor Mascarville (31.30) is the asymmetry due to r-deletion 'repaired', indicating that r-less SC forms are perceived as more systemic than vocalic asymmetry. 
Preprint of: Esher, Louise. 2015. Formal asymmetries between the Romance synthetic future and conditional in the Occitan varieties of the Western Languedoc. Transactions of the Philological Society 113(2). 249-270.

\begin{tabular}{llll}
\hline lexeme & SF.3SG & SC.3SG & localities \\
\hline veire 'see' & $\begin{array}{l}\text { veirà } / \beta \mathrm{ej} \text { ' } \mathrm{ra} / \\
\text { virà } / \beta \mathrm{i} \text { 'ra/ }\end{array}$ & vi(r)iá $/ \beta \mathrm{i}{ }^{\prime} \mathrm{j}$ / & $31.12,31.30$ \\
\end{tabular}

Table 4. Symmetry restored by analogy.

The monophthongisation which gives rise to asymmetry is lexically diffuse throughout. Together, the survey points at which such asymmetry occurs form a coherent geographical area, but the same cannot be said if the map is drawn for each individual lexeme (Figure 2): at many survey points, even lexemes with a near-identical phonological shape, such as veire 'see' and creire 'believe', behave differently from each other with respect to the presence or absence of asymmetry between the SF and SC stems. These individual patterns of distribution resist explanation in terms of either human or physical geography.

\subsection{Asymmetry of stem-final consonant clusters}

Among the most frequently attested asymmetries is an opposition between $/ \mathrm{ld} \mathrm{r} /$ and $/ \mathrm{d} r /, / \mathrm{d} r /$ and $/ \mathrm{r} /$, or $/ \mathrm{R} /$ and $/ \mathrm{r} /$ in the SF and SC of verbs such as voler 'want', valer 'be worth' and caler/faler 'be necessary', which would have presented a consonant cluster -lr- or -nr- in mediaeval Occitan (see e.g. Ronjat 1932:229). A sample of the asymmetries observed for voler is given in Table 5; in general, at a given survey point, all verbs potentially subject to this type of asymmetry present the same distribution.

Most commonly, the stem of greater phonological substance is found in the SF, but the opposite distribution is also widespread, and many informants spontaneously produce two variants, or add a second variant in careful speech. Given both the extensive variation encountered and the very systematic phonological context at issue, it appears likely that asymmetries of this third type are a product of synchronic phonology, and, unlike the r-less SC forms or vocalic asymmetries, have not become morphologised. 
Preprint of: Esher, Louise. 2015. Formal asymmetries between the Romance synthetic future and conditional in the Occitan varieties of the Western Languedoc. Transactions of the Philological Society 113(2). 249-270.

\begin{tabular}{|c|c|c|}
\hline SF.3SG & SC.3SG & localities \\
\hline vorrà / $\beta \mathrm{u}^{\prime} \mathrm{Ra} /$ & voriá / $\beta$ u'rjo/ & $81.32,47.12,47.02,47.03,47.05,24.32,24.22,24.21$ \\
\hline vorrà / $\beta \mathrm{u}^{\prime} \mathrm{Ra} /$ & $\begin{array}{l}\text { voriá / } \beta \mathrm{u}^{\prime} \text { гjo/ } \\
\text { vorriá / } \beta \mathrm{u}^{\prime} \mathrm{Rj} \mathrm{s} /\end{array}$ & $46.13,12.21$ \\
\hline vodrà & $\begin{array}{l}\text { voriá } \\
\text { (vodriá, careful speech) }\end{array}$ & 81.35 \\
\hline vodrà /bu'dra/ & voriá /bu'rjo/ & $82.20,47.14$ \\
\hline vodrà & vorriá & 33.11 \\
\hline vodrà & vodriá, vorriá & 81.04 \\
\hline vorrà & vodriá & 81.31 \\
\hline voldrà & vodrá, voldrá & 11.04 \\
\hline voldrà & vodriá & 81.06 \\
\hline voldrà & vodriá, voldriá & 81.22 \\
\hline voldrà & vodrá & 81.23 \\
\hline vodrà / $\beta$ u'dra/ & voldrá / $\beta \mathrm{ul}$ 'dø/ & 82.01 \\
\hline
\end{tabular}

Table 5. Illustrative sample of consonant cluster asymmetries for voler 'want'.

\subsection{Summary}

The ALLOc data attest three recurrent types of asymmetry due to phonological processes: r-less SC forms, vocalic asymmetry and consonant cluster asymmetry. Of these, the first two types appear to have been morphologised, whereas the third is still subject to synchronic variation. The r-less SC forms are particularly significant, since this type of asymmetry is very common (widespread in the survey area, attested for several other varieties of Occitan, and occurring in the conjugation with highest type and token frequency), and there is some evidence for it having been extended by analogy to other conjugational classes, such that the r-less pattern becomes increasingly systematic. The appearance of r-less SC forms is argued to create a morphological precedent for asymmetry between SF and SC. 
Preprint of: Esher, Louise. 2015. Formal asymmetries between the Romance synthetic future and conditional in the Occitan varieties of the Western Languedoc. Transactions of the Philological Society 113(2). 249-270. - $\quad$-less SC systematic in first conjugation
$\quad$ r-less SC in some first conjugation forms

- $\quad r$-less SC systematic in second conjugation r-less SC in some second conjugation forms

- r-less SC systematic in regular third conjugation

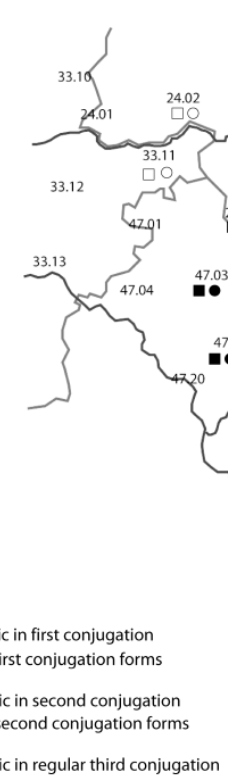

Figure 1. Geographical distribution of r-less SC forms 
Preprint of: Esher, Louise. 2015. Formal asymmetries between the Romance synthetic future and conditional in the Occitan varieties of the Western Languedoc. Transactions of the Philological Society 113(2). 249-270.

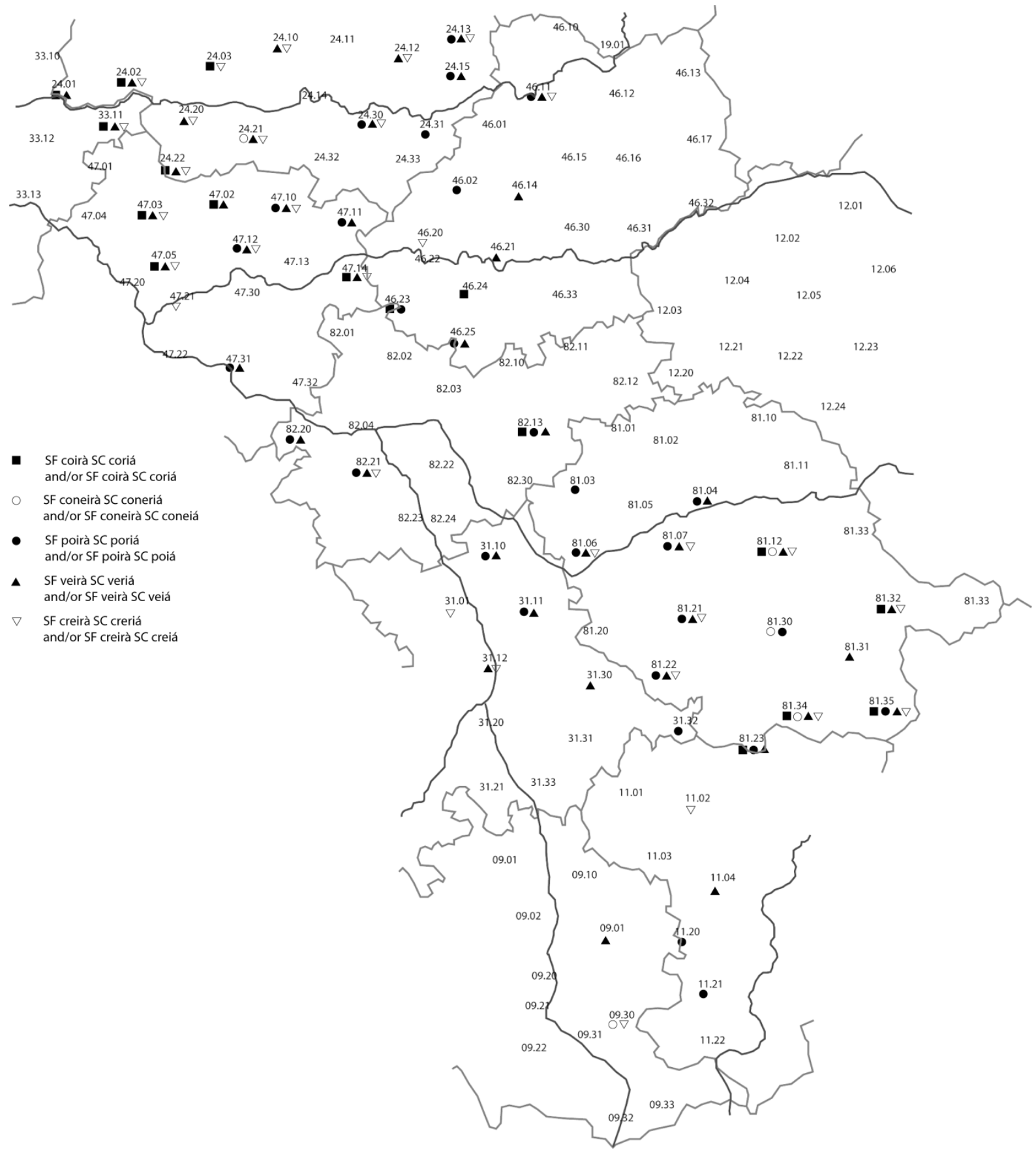

Figure 2. Geographical distribution of vocalic asymmetry by monophthongisation. 
Preprint of: Esher, Louise. 2015. Formal asymmetries between the Romance synthetic future and conditional in the Occitan varieties of the Western Languedoc. Transactions of the Philological Society 113(2). 249-270.

\section{ASYMMETRIES OF CONJUGATIONAL CLASS}

Further categories of asymmetry involve a difference of conjugational class between SF and SC. In such cases it is typical (though not exceptionless), for either the SF or SC to present a form consistent with the conjugational class of other wordforms for the same lexeme, while the SC or SF presents a form characteristic of a different conjugational class. These are cases of 'heteroclisis' (Stump 2006:279), since the inflectional paradigms of the lexemes involved each include forms belonging to at least two distinct conjugational classes. Heteroclisis is common in Occitan varieties (see e.g. Bach \& Esherforthcoming), where, as in Daco-Romance (Maiden 2009b), the distribution of the different inflectional class forms within the paradigm typically corresponds to existing metamorphomic distributions: for instance, heteroclisis affects both the preterite and imperfect subjunctive (i.e. the constituent members of the metamorphome 'PYTA', Maiden 2005), or neither. Indeed, the grammars of Allanche (1941), Alibèrt (1976) and Lignières (1951) all attest several cases of Fuèc forms unitarily belonging to a separate conjugational class from all other wordforms in the same lexeme. The ALLOc transcriptions provide further examples of such distributions, but also attest a type of distribution which, again, few grammars recognise: heteroclite asymmetry between SF and SC.

\subsection{Systemic heteroclite asymmetry}

The ALLOc data indicate not merely that heteroclite asymmetry exists, but that it is, in some cases, systemic. In Cambes (47.03) and Labretonie (47.05), the regular third-conjugation verb batre 'beat' representing has the expected, etymological Fuèc stem without theme vowel in the SF, but a stem of firstconjugation type in the SC (Table 6). In Labretonie, the SC straightforwardly presents the etymological first-conjugation theme vowel /a/ (found in both SF and SC of the first conjugation), and this asymmetric pattern is being extended by analogy to irregular verbs (Table 7). In Cambes, however, the first conjugation is itself asymmetric, with a contrast between SF /kanto' ro/ 'sing.SF.3 sg' ${ }^{16}$ and SC/kante' jo/. It is significant that r-less SC forms are found in all conjugations in both these varieties.

\begin{tabular}{|c|c|c|c|}
\hline lexeme & SF.1SG & SC.1SG & localities \\
\hline \multirow[t]{2}{*}{ vendre 'sell' } & vendrèi / $\beta$ en'drcj/ & vende(r)iái /ßende'joj/ & 47.03 \\
\hline & vendrèi & venda(r)iái/ßenda'joj/ & 47.05 \\
\hline
\end{tabular}

Table 6. Systematic asymmetry of conjugational class.

${ }^{16}$ Cambes is within the northern area in which /a/ is backed and raised; /kanto'ro/ is thus phonologically regular. 
Preprint of: Esher, Louise. 2015. Formal asymmetries between the Romance synthetic future and conditional in the Occitan varieties of the Western Languedoc. Transactions of the Philological Society 113(2). 249-270.

\begin{tabular}{llll}
\hline lexeme & SF.3SG & SC.3SG & localities \\
\hline recebre 'receive' & recebrà & receba(r)iá & 47.05 \\
\hline téner 'hold' & tendrà & tenda $(r) i a ́$ & 47.05 \\
\hline
\end{tabular}

Table 7. Asymmetry of conjugational class by analogy.

In synchrony, it is questionable whether the distributions observed for Cambes and Labretonie can be termed heteroclite: batre does not instantiate a 'mixed' class combining elements of distinct classes I and III, since there is no class III pattern other than that of batre. By contrast, in diachrony this is clearly a case of heteroclisis, and, interestingly, one which respects a different type of morphomic distribution: the division of the lexicon into inflectional classes, termed 'rhizomorphomes' in the typology of Round (in prep.). In Cambes and Labretonie, asymmetric heteroclisis does not affect scattered or disparate lexemes, but applies to all members of a given inflectional class. These data support and extend Maiden's (2009b) point that heteroclisis follows established morphomic distributions: the distributions in question are not limited to the metamorphomes illustrated by Maiden, but also include rhizomorphomes. ${ }^{17}$

\subsection{Sporadic heteroclite asymmetry}

As with vocalic asymmetry, it is more often the case that heteroclite asymmetry occurs only in a few lexemes within a given variety. Most likely to be affected are lexemes originally of conjugational class IIIb (e.g. córrer 'walk/run', nàisser 'be born') - a minority variant of the third conjugation, which is distinguished from other third-conjugation verbs by the presence of a thematic vowel/e/ in Fuèc. Verbs of class IIIb are particularly susceptible to analogical change, including heteroclisis.

The most frequently encountered pattern of asymmetric heteroclisis is shown in Table 8: the SF retains the original IIIb form with /e/, while the SC adopts the theme vowel /i/ characteristic of the second conjugation, and the rest of the paradigm is unaffected. This pattern is also attested by Deledar (2006) for the Volvestre area in the west of the département Ariège. There is some variation: in Bioule (82.13), the informant gives both molze(r)iá and molzi(r)iá for the SC, while in Degagnac (46.02) the informant accepts the fieldworker's suggestion of correriá. The theme vowel /i/ may subsequently be introduced into the SF, as in Degagnac and Capdenac-le-Haut (46.32).

The existence of a systematic conjugational contrast between /e/ and /i/ invites interpretation of the contrasts in Table 8 as heteroclite, and the fact that the theme vowel /i/ can be extended into the SF to restore symmetry suggests that speakers do consider the presence of /i/ to be a morphological (rather than e.g. phonological) attribute of the innovative SC forms. However, it is important to recognise that neither of these observations entails that the asymmetries listed must have arisen via morphological analogy alone all the more so as, strikingly, there are no confirmed instances of asymmetry in the opposite direction,

${ }^{17}$ I am grateful to Xavièr Bach for drawing this point to my attention. 
Preprint of: Esher, Louise. 2015. Formal asymmetries between the Romance synthetic future and conditional in the Occitan varieties of the Western Languedoc. Transactions of the Philological Society 113(2). 249-270.

between an /i/-form in the SF and an /e/-form in the SC. ${ }^{18}$ Indeed, it is probable that the asymmetries shown in Table 8 are originally caused by metaphony, with etymological/e/ in the SC raising to /i/ under the influence of the following /i/ or /j/. In this case, therefore, as in $\$ 3.1$ and $\$ 3.2$, morphological asymmetry arises from a context-sensitive phonological change. The particularity of the asymmetries shown in Table 8 , in contrast to the r-less SC forms or vocalic asymmetry, is that the outcome of the sound change maps onto an existing formal stem distinction which is well-established within the morphological system, thus favouring the possibility of speakers reanalysing a phonological opposition as morphological.

\begin{tabular}{|c|c|c|c|}
\hline lexeme & SF.3SG & SC.3SG & localities \\
\hline \multirow{3}{*}{ conéisser 'know' } & coneguerà & coneguirá $^{19}$ & 09.21 \\
\hline & coneisherà & coneishiriá & 09.32 \\
\hline & conesherò & coneshiriá & 46.17 \\
\hline \multirow[t]{4}{*}{ córrer 'walk/run' } & correrò & corririá & 46.17 \\
\hline & $\begin{array}{l}\text { correrà } \\
\text { corrirà }\end{array}$ & corririá & 46.32 \\
\hline & corrirà & corririá & 46.02 \\
\hline & correrà & correriá (suggested) & \\
\hline cóser 'cook' & coserà & $\operatorname{cosi}(r) i a ́$ & $46.25,47.21$ \\
\hline \multirow[t]{2}{*}{ créisser 'grow' } & creisherà & creishi(r)iá & $24.30,46.23$ \\
\hline & creisserà & creissi(r)iá & 47.14 \\
\hline mólzer 'milk' & molzerà & molze(r)iá, molzi(r)iá & 82.13 \\
\hline \multirow[t]{4}{*}{ nàisser 'be born' } & naisherà & naishiriá & 46.13 \\
\hline & naisserà & naissi(r)iá & $82.13,46.25,47.14,81.34,81.35$ \\
\hline & naisherà & naishi(r)iá & $46.17,24.30,46.23$ \\
\hline & nèisserà & nèissi(r)iá & 47.11 \\
\hline \multirow[t]{2}{*}{ sègre 'follow' } & sieguerà & siegui(r)iá & 82.20 \\
\hline & sieguerà & segui(r)iá & 82.21 \\
\hline venir 'come' & venguerà & vengui(r)iá & 82.20 \\
\hline
\end{tabular}

Table 8. Asymmetry of conjugational class: SF IIIb (etymological), SC II (innovative).

Another common type of conjugational class asymmetry involves a contrast between third-conjugation forms with no theme vowel (IIIa, typically in the SF) and forms of the IIIb pattern (typically in the SC), as exemplified in Table 9. The difference between IIIa and IIIb inflectional patterns is minimal, hinging on the infinitive and Fuèc. It results essentially from variation between syncopated and apocopated forms, the latter e.g. coserà, vederà, beverà being more common in south-western varieties of Occitan (see e.g. ALG

\footnotetext{
18 The only attestation of such a distribution found within the ALLOc data is a contrast between seguirà 'follow.SF.3sg' and segue(r)iá 'follow.SC.3sg' in Merville (31.01).

${ }^{19} \mathrm{Sic}$, for /kuneyiro/. In Surba (09.21), as in several varieties of southern Ariège, / $\mathrm{j} /$ has been deleted from all SC desinences.
} 
Preprint of: Esher, Louise. 2015. Formal asymmetries between the Romance synthetic future and conditional in the Occitan varieties of the Western Languedoc. Transactions of the Philological Society 113(2). 249-270.

vol. V-2:77), while the former e.g. coirà, veirà, beurà are more common to the east. Within the ALLOc survey area, such variation chiefly affects the verbs 'cook' and 'know', and this is reflected in the cases of asymmetry observed. The forms given in Table 9 for 'cook' in Sonnac (11.20), Blanquefort (47.11), Tayrac (47.32) and Boudou (82.04) show interaction of IIIa/IIIb variation with the raising of /e/ to /i/ in the SC stem, while in Faux (24.21) there is interaction with vocalic asymmetry, and several of the SC forms have undergone r-deletion.

In the case of the verb 'know', the additional IIIa forms in -tr- may reflect French influence; it should, though, be borne in mind that conetrà, etc. can equally result from regular sound change, as in the Limousin, where such forms are standard (see e.g. Lavalade 1987, Reydy 2008), or by analogy with other thirdconjugation verbs with Fuèc forms in -tr- or -dr-, a possible instance of 'convergence' (Maiden 2005), in which the exponents of a given metamorphome assume a phonological resemblance across lexemes. The distributions in Table 10 result from variation between several possible (and plausibly etymological) Fuèc stems for the lexeme 'cook'.

Table 11 shows asymmetries resulting from the progressive spread of an epenthetic vowel into the SF and $\mathrm{SC}$ forms of the lexemes 'receive' and 'be able', in a variety in which the majority third-conjugation pattern is for the theme vowel /e/ to be present throughout Fuèc.

\begin{tabular}{|c|c|c|c|}
\hline lexeme & SF.3SG & SC.3SG & locality \\
\hline \multirow[t]{10}{*}{ cóser 'cook' } & cojerà & coriá & 46.02 \\
\hline & & cojeriá & \\
\hline & coirà & coseriá & $81.03,46.21$ \\
\hline & coirà & cose(r)iá & 47.31 \\
\hline & coirá & cose(r)iá & 24.21 \\
\hline & & co(r)iá & \\
\hline & queirà & queirá & 11.20 \\
\hline & & quesiriá & \\
\hline & coirà & $\operatorname{cosi}(r) i a ́$ & $47.11,47.32$ \\
\hline & cosirà, coirà & cosi(r)iá & 82.04 \\
\hline \multirow[t]{4}{*}{ conéisser 'know' } & coneirà & coneisseriá & 81.35 \\
\hline & conetrà, conesserà & conesseriá & 46.01 \\
\hline & conetrà & conetriá, & 46.13 \\
\hline & conesherà & $\begin{array}{l}\text { conesheriá, } \\
\text { coneshiriá }\end{array}$ & \\
\hline \multirow[t]{2}{*}{ claure 'close' } & clauserà & clauriá & 82.13 \\
\hline & & clauseriá & \\
\hline
\end{tabular}

Table 9. SC shifting to IIIb.

lexeme

SF.3SG

SC.3SG

locality 
Preprint of: Esher, Louise. 2015. Formal asymmetries between the Romance synthetic future and conditional in the Occitan varieties of the Western Languedoc. Transactions of the Philological Society 113(2). 249-270.

$\begin{array}{llll}\text { conéisser 'know' } & \begin{array}{l}\text { coneshirà } \\ \text { conetrà } \\ \text { conetrà }\end{array} & \begin{array}{l}\text { coneirá } \\ \text { coneshirá }\end{array} & 11.03 \\ & \text { coneirá } & 82.10\end{array}$

Table 10. Distinct IIIa stems.

$\begin{array}{llll}\text { lexeme } & \text { SF.3SG } & \text { SC.3SG } & \text { locality } \\ \text { recebre 'receive' } & \text { recebrà, receberà } & \text { recebe(r)iá } & 31.01 \\ \text { poder 'be able' } & \text { podrà, poderà } & \text { pode }(r) i a ́ & 31.01\end{array}$

Table 11. Asymmetry in Merville (31.01)

The rarest heteroclite asymmetries of all are those involving first-conjugation forms (Table 12); these too tend to occur in lexemes originally belonging to class IIIb. In contrast to many other types of asymmetry, there is no general directionality: in Saint-Martin-Lalande (11.02), 'be born' has theme vowel /a/ in the SF and /e/ in the SC, while 'know', despite having a similar phonological shape, has /e/ in the SF and /a/ in the $\mathrm{SC}$, as does 'be born' in Appelle (81.22); the varieties of Dreuilhe (31.32) and Tayrac (47.32) show realtime variation between /a/ and /e/. In both Labretonie (47.05) and Saint-Martin-Lalande (11.02), asymmetric heteroclisis introducing first-conjugation forms into the $\mathrm{SF}$ is coupled with raising of /e/ to /i/ in the SC; the result is an exotic-seeming opposition between the theme vowels /a/ and / $\mathrm{i} /$, characteristic of the first and second conjugations respectively, within an otherwise third-conjugation lexeme.

Wholesale replacement of /e/ in Fuèc forms by first-conjugation /a/ is robustly attested in the ALLOc data, and is also mentioned in some descriptive grammars, such as that of Allanche (1941). This development is entirely consistent with the generalisations of Bybee (2001) and Albright (2009) concerning the role of frequency in determining models and targets for analogy, since it illustrates the replacement of a pattern which has both low type frequency within the lexicon and low token frequency in usage, by a pattern of high frequency in both respects. The introduction of first-conjugation /a/ into the Fuèc forms of IIIb lexemes thus has a plausible morphological motivation. The variability and lack of directionality manifest in Table 12 suggest that asymmetries between I- and IIIb-type forms may result from a change in progress assimilating the Fuèc forms of IIIb lexemes to the first-conjugation pattern. 
Preprint of: Esher, Louise. 2015. Formal asymmetries between the Romance synthetic future and conditional in the Occitan varieties of the Western Languedoc. Transactions of the Philological Society 113(2). 249-270.

\begin{tabular}{llll}
\hline lexeme & SF.3SG & SC.3SG & locality \\
\hline conéisser 'know' & coneissarà & coneisse(r)iá & 24.22 \\
\hline córrer 'walk/run' & corruerà & correré & 47.01 \\
\cline { 2 - 4 } & corrarà & corre(r)iá & 24.10 \\
\cline { 2 - 4 } & corrarà & corri(r)iá & 47.05 \\
\hline créisser 'grow' & creissarà & creisse(r)iá & $82.03,24.21$ \\
\hline nàisser 'be born' & naissarà & naisse $(r) i a ́$ & $11.02,31.11,82.03$ \\
\cline { 2 - 4 } & naissarà & naisseriá & 12.24 \\
\hline mólzer 'milk' & molzarà & molze $(r) i a ́$ & 31.30 \\
\cline { 2 - 4 } & muzarà & muzi $(r) i a ́$ & 11.02 \\
\hline conéisser 'know' & coneisserà & creissa $(r) i a ́$ & 31.32 \\
\hline créisser 'grow' & creisserà & naissariá & 81.22 \\
\hline nàisser 'be born' & naisserà & coneissa $(r) i a ́$ & 31.32 \\
\hline conéisser 'know' & coneisserà, coneissarà & conesse(r)iá, conessa(r)iá & 47.32 \\
\cline { 2 - 4 } & conesserà & creissa $(r) i a ́$ & 47.32 \\
\hline créisser 'grow' & creisserà, creissarà & \\
\hline
\end{tabular}

Table 12. SF I \& IIIb, SC I

\subsection{Summary}

Three main categories of conjugational class asymmetry are found in the ALLOc data, all affecting thirdconjugation lexemes. A systematically directional contrast between theme vowel /e/ in the SF and theme vowel / $\mathrm{i} /$ in the $\mathrm{SC}$ is argued to result from metaphonic raising, and to be interpretable by speakers as a case of heteroclisis because the outcome of raising happens to coincide with the existing second-conjugation theme vowel /i/. Alternation between theme vowel /e/ and absence of theme vowel is chiefly confined to the lexemes 'cook' and 'know', which show regional variation in the early deletion and epenthesis of vowels. Non-directional alternation between /e/ and first-conjugation /a/ in lexemes of class IIIb results from sporadic morphological analogy replacing a low-frequency pattern by a pattern of much higher frequency.

Given the existence of distributions in which both SF and SC present, for example, the same innovative theme vowel, it is possible that such asymmetries represent a transitional stage. Nevertheless, it is significant that the majority of cases discussed in this section occur in varieties which also present vocalic asymmetry, r-less SC forms or both; the exceptions to this generalisation are the asymmetries due to metaphony, which may themselves be considered of independent phonological origin. These findings suggest that the presence of one type of asymmetry may favour others, and that morphologised asymmetries of phonological origin may precede asymmetries of morphological origin. Once again, the data thus indicate an important role for sound change in creating novel morphological distributions, which speakers may integrate as morphomic templates. 
Preprint of: Esher, Louise. 2015. Formal asymmetries between the Romance synthetic future and conditional in the Occitan varieties of the Western Languedoc. Transactions of the Philological Society 113(2). 249-270.

\section{ASYMMETRY BY MORPHOLOGICAL ANALOGY}

The most striking type of asymmetry results from processes which are unambiguously morphological: analogical extension of a root or stem present elsewhere in the paradigm into the SF or SC, or remodelling of an SF or SC stem based on partial analogy with another lexeme. Such asymmetries are rare, geographically scattered, and heterogeneous in terms of the lexemes affected and the resulting paradigmatic distributions. While the majority are wholly morphological, some display interaction with phonology.

\subsection{Influence of the PYTA root}

In the Occitan varieties of the ALLOc survey area, most second-conjugation verbs and irregular thirdconjugation verbs present a distinctive root in the preterite and imperfect subjunctive (i.e. the metamorphome PYTA ${ }^{20}$ ). As in many varieties of Occitan, the characteristic PYTA root also commonly occurs in the present subjunctive (see Maiden 1996, Wheeler 2011). The PYTA root thus has relatively high type frequency within the paradigm, and is not infrequently extended to Fuèc as a whole, but the ALLOc data also attest a handful of cases in which the PYTA root is extended asymmetrically, serving as a model for innovative forms either in the SF or the SC. Examples of such extension are given in Table $13^{21}$; as can be seen from these data, there is considerable variation in the lexemes affected, the element spread by analogy, and the resulting distribution. ${ }^{22}$

For the verb 'follow' in Cancon (47.12) and Roquecor (82.01), a PYTA root setg-is extended to Fuèc. In Cancon, a stem based on the root setg-entirely replaces the etymological form of the SF, while in Roquecor the stem based on setg-occurs in the SC, alongside the etymological form. In both cases, the extension of setg- is correlated with the extension of the second-conjugation thematic vowel /i/. However, the velar element characteristic of PYTA in Roquecor is not spread into the SC, *setgigue(r)iá. Although the phonological forms of the same verb in Lauzerte (82.02) are rather different, their distribution is strikingly similar to that found in Cancon. ${ }^{23}$

In Donzac (82.20), asymmetrical extension of the PYTA root affects the verb 'go', a lexeme already prone to incursive suppletion across Romance varieties, including in Occitan where the Fuèc stem frequently results from a cross between reflexes of AMBULARE and IRE. The SC stem in Donzac is of precisely this

${ }^{20}$ PYTA comprises the surviving reflexes of Latin perfectum forms. See Maiden (2005) for discussion.

${ }^{21}$ Infinitive forms in this and subsequent tables are those of the individual localities.

${ }^{22}$ Analogy with the PYTA root may also be implicated in the contrast between SF deurá and SC douriá for deure 'have to' in Saint-Julien-de-Crempse (24.03); compare PRS.IND deu, IMPF.IND deviá, PRS.SBJV degue, PRET dougué, IMPF.SBJV dougué. However, the data offer limited evidence for such analogy, as only the stem vowel /ow/ is shared between PYTA and the SC. Furthermore, a similar alternation between /ew/ in the SF and /ow/ in the SC is attested for the verb plèure 'rain' in Les Leves (33.11), a lexeme in which no wordform other than the SC presents the sequence /ow/. Either the alternation in Les Leves is an error, or it has a motivation independent of analogy with PYTA, to which the alternation in Saint-Julien might also be attributable.

${ }^{23}$ The 1PL and 3PL preterite retain the etymological velar consonant of the lexical root, which strengthens the case for attributing the SF form to influence from PYTA. 
Preprint of: Esher, Louise. 2015. Formal asymmetries between the Romance synthetic future and conditional in the Occitan varieties of the Western Languedoc. Transactions of the Philological Society 113(2). 249-270.

origin, but the SF stem is based instead on the PYTA root ang-. Here too there are elements of the PYTA forms which are not spread into the SF: here, the third-conjugation PYTA theme vowel $/ \mathrm{u} /$.

The reflex of CRESCERE has undergone asymmetrical extension of the PYTA root in two varieties, those of Fauch (81.12) and Jouels (12.22). In both these cases, the SF maintains the etymological form in creisser/creisher-, while the SC is remodelled on the PYTA root cresc-. The only difference concerns the thematic element: in Jouels, the thematic vowel /e/ is maintained in the new SC form, while in Fauch it is lost.

In Foulayronnes (47.31), for the verb 'believe', the root $/ \mathrm{krets} /$ with its thematic vowel /e/ common to the present subjunctive, preterite and imperfect subjunctive is extended to the SC, incidentally creating an asymmetry of conjugational class between the SF (IIIa) and the SC (IIIb, very much a minority type within this variety). As in Roquecor, the velar element is not spread to the SC *cretgegue(r)iá.

Overall, there appears to be a slight preference for the PYTA root to be spread into the SC rather than the $\mathrm{SF}$, but with so few data overall (due to the rarity of asymmetry by morphological analogy), this preference cannot reliably be considered significant.

\begin{tabular}{|c|c|c|c|c|c|c|c|}
\hline lexeme & PRS.IND & IMPF.IND & PRS.SBJV & PRET & IMPF.SBJV & SF & $\mathrm{SC}$ \\
\hline $\begin{array}{l}\text { siègre } \\
\text { 'follow' } \\
47.12\end{array}$ & $\begin{array}{l}\text { sièt } \\
\text { sjet }\end{array}$ & $\begin{array}{l}\text { setgiá } \\
\text { set'sjo }\end{array}$ & $\begin{array}{l}\text { siètge } \\
\text { 'sjetse }\end{array}$ & $\begin{array}{l}\text { setgièt } \\
\text { setsi'zt }\end{array}$ & $\begin{array}{l}\text { setgièsse } \\
\text { setsi'Ese }\end{array}$ & $\begin{array}{l}\text { setgirà } \\
\text { setsi'ra }\end{array}$ & $\begin{array}{l}\text { segriá } \\
\text { se'grjo }\end{array}$ \\
\hline $\begin{array}{l}\text { siègre } \\
\text { 'follow' } \\
82.01\end{array}$ & $\begin{array}{l}\text { sièc } \\
\text { sjek }\end{array}$ & $\begin{array}{l}\text { sieguiá } \\
\text { sje'gjo }\end{array}$ & $\begin{array}{l}\text { siègue } \\
\text { 'sjege }\end{array}$ & $\begin{array}{l}\text { setgiguèt } \\
\text { setsi'get }\end{array}$ & $\begin{array}{l}\text { setgiguèsse } \\
\text { setsi'gese }\end{array}$ & $\begin{array}{l}\text { siegrà } \\
\text { sje'gra }\end{array}$ & $\begin{array}{l}\text { siegrá, } \\
\text { setgi(r)iá } \\
\text { sje'gro, } \\
\text { setsi'rjo }\end{array}$ \\
\hline $\begin{array}{l}\text { siègre } \\
\text { 'follow' } \\
82.02\end{array}$ & $\begin{array}{l}\text { sièc } \\
\text { sjek }\end{array}$ & $\begin{array}{l}\text { si(gu)iá } \\
\text { si'jo }\end{array}$ & $\begin{array}{l}\text { siègue } \\
\text { 'sjege }\end{array}$ & $\begin{array}{l}\text { si(gu)èt } \\
\text { si'ct }\end{array}$ & $\begin{array}{l}\text { si(gu)èsse } \\
\text { si'zse }\end{array}$ & $\begin{array}{l}\text { sigrà } \\
\text { sig'ra }\end{array}$ & $\begin{array}{l}\text { siegrá } \\
\text { sjeg'ro }\end{array}$ \\
\hline $\begin{array}{l}\text { anar } \\
\text { 'go' } \\
82.20\end{array}$ & $\begin{array}{l}\text { vai } \\
\text { baj }\end{array}$ & $\begin{array}{l}\text { anava } \\
\text { a'naßo }\end{array}$ & $\begin{array}{l}\text { angue } \\
\text { 'ãnge }\end{array}$ & $\begin{array}{l}\text { angót } \\
\text { ãyg'ut }\end{array}$ & $\begin{array}{l}\text { angósse } \\
\text { ãng'use }\end{array}$ & $\begin{array}{l}\text { anguerà } \\
\text { ãnge'ra }\end{array}$ & $\begin{array}{l}\text { ani(r)iá } \\
\text { ani'o }\end{array}$ \\
\hline $\begin{array}{l}\text { créisser } \\
\text { 'grow' } \\
81.12\end{array}$ & $\begin{array}{l}\text { creis } \\
\text { krejs }\end{array}$ & $\begin{array}{l}\text { creissiá } \\
\text { krej'sjo }\end{array}$ & $\begin{array}{l}\text { cresque } \\
\text { 'kreske }\end{array}$ & $\begin{array}{l}\text { cresquèt } \\
\text { kres'ket }\end{array}$ & $\begin{array}{l}\text { cresquèssa } \\
\text { kres'keso }\end{array}$ & $\begin{array}{l}\text { creisserà } \\
\text { krzjse'ra }\end{array}$ & $\begin{array}{l}\text { crescriá } \\
\text { kres'krjo }\end{array}$ \\
\hline $\begin{array}{l}\text { créisher } \\
\text { 'grow' } \\
12.22\end{array}$ & $\begin{array}{l}\text { creish } \\
\text { krej }\end{array}$ & $\begin{array}{l}\text { creishiá } \\
\text { krعj'Jjo }\end{array}$ & $\begin{array}{l}\text { cresca } \\
\text { 'krehko }\end{array}$ & $\begin{array}{l}\text { cresquèt } \\
\text { krek'ket }\end{array}$ & $\begin{array}{l}\text { cresquèssa } \\
\text { kreh'keso }\end{array}$ & 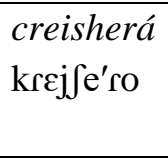 & $\begin{array}{l}\text { cresqueriá } \\
\text { krehke'rjo }\end{array}$ \\
\hline $\begin{array}{l}\text { creire } \\
\text { 'believe' } \\
47.31\end{array}$ & $\begin{array}{l}\text { crei } \\
\text { krej }\end{array}$ & $\begin{array}{l}\text { cregiá } \\
\text { kre'zjo }\end{array}$ & $\begin{array}{l}\text { cretge } \\
\text { 'kretse }\end{array}$ & $\begin{array}{l}\text { cretgeguèt } \\
\text { kretse'get }\end{array}$ & $\begin{array}{l}\text { cretgeguèssa } \\
\text { kretse'geso }\end{array}$ & $\begin{array}{l}\text { creirà } \\
\text { krej'ra }\end{array}$ & $\begin{array}{l}\text { cretge(r)iá } \\
\text { kretse'jo }\end{array}$ \\
\hline
\end{tabular}

Table 13. Asymmetry by analogy with the PYTA root. 
Preprint of: Esher, Louise. 2015. Formal asymmetries between the Romance synthetic future and conditional in the Occitan varieties of the Western Languedoc. Transactions of the Philological Society 113(2). 249-270.

\subsection{Influence of the $N$-pattern root and the $N$-pattern complement root}

The morphome labelled 'N-pattern' by Maiden (e.g. 2009a) comprises the singular and 3PL forms of the present indicative (and sometimes also of the present subjunctive), together with the 2 sG imperative form. ${ }^{24}$ In the ALLOc data, there are two attestations of asymmetry which can be directly attributed to the influence of the N-pattern root (Table 14). In Merens-les-Vals (09.32) and Rabastens (81.06), the verb 'cook' presents asymmetry involving propagation of the vowel / $/$, found in the N-pattern root, into the SF, while the SC retains its etymologically expected stem vowel $/ \mathrm{u} /$.

\begin{tabular}{|c|c|c|c|c|c|c|c|}
\hline lexeme & PRS.IND & IMPF.IND & PRS.SBJV & PRET & IMPF.SBJV & SF & $\mathrm{SC}$ \\
\hline còire & còtg & cosiá & còse & cosèc & cosès & còirà & coiria \\
\hline $\begin{array}{l}\text { koj're } \\
\text { 'cook' } 09.32\end{array}$ & 'kots & ku'zjo & 'koze & ku'zek & $\mathrm{ku}^{\prime} \mathrm{z} \varepsilon \mathrm{s}$ & koj'ra & kuj'ria \\
\hline còser & $c o ̀ i$ & cosiá & $\operatorname{coseg} a$ & coseguèt & coseguèssa & còserà & $\operatorname{cose}(r) i a ́$ \\
\hline $\begin{array}{l}\text { koze } \\
\text { 'cook' } 81.06\end{array}$ & 'koj & ku'zjo & ku'zeуo & kuze'yet & kuze'yeso & koze'ra & kuze'jo \\
\hline
\end{tabular}

Table 14. Asymmetry by analogy with the N-pattern root.

Maiden \& Smith (2014) discuss a number of cases in French, Italian and eastern varieties of Occitan, in which the N-pattern root has been spread into Fuèc. They propose that such extensions are due to analogy with existing patterns, in which the stem found in the N-pattern presents a 'fortuitous' but systematic identity with the Fuèc stem: for instance, in Italian, venderà 'sell.SF.3SG' not only includes exactly the same sequence of segments as vende 'sell. PRS.IND.3SG', but also presents a prosodic similarity, as (primary) stress on the root is a salient exponent of the N-pattern, and the Fuèc stem typically bears secondary stress. Maiden \& Smith suggest that identities such as this are likely to have constituted a precedent for the extension of a stem associated with the N-pattern into Fuèc. A similar case can be made for the SF forms given above; though, as the argument from stress would also be applicable to the SC (and may indeed account for the N-pattern-like stem vowel of the SC form siegrá 'follow.SC.3SG' in Table 13 above), such an argument does not predict asymmetry between SF and SC.

Certain other cases, shown in Table 15, may also be linked to the spread of the N-pattern root, albeit less directly. Whereas in Merens-les-Vals and Rabastens the innovative SF form uniquely shares a root with the $\mathrm{N}$-pattern cells, in the data given in Table 15 the N-pattern root has also spread to other areas of the paradigm. For instance, in the verb 'open' in Villaudric (31.10), the N-pattern root dièrb- has been extended

\footnotetext{
${ }^{24}$ See Maiden (2009a) for the history of the N-pattern and examples from other Romance varieties. Examples of Npattern stem alternation in Occitan varieties of the Languedoc include the suppletive pattern found in anar 'go', in which the N-pattern cells present reflexes of UADERE 'go' while other paradigm cells continue AMBULARE or IRE; stem vowel alternation between / $\mathrm{o} / \mathrm{N}$-pattern) and / $\mathrm{u} /$ (elsewhere), as in the examples in Table 14; and stem vowel alternation between $/ \varepsilon /(\mathrm{N}$-pattern) and /e/ (elsewhere). The term N-pattern is deliberately chosen as an abstract label to refer to the set of cells independently of extramorphological features.
} 
Preprint of: Esher, Louise. 2015. Formal asymmetries between the Romance synthetic future and conditional in the Occitan varieties of the Western Languedoc. Transactions of the Philological Society 113(2). 249-270.

to the imperfect indicative and imperfect subjunctive, as well as to the SF. ${ }^{25}$ In Labastide-de-Lordat (09.10), as in Lauzerte and Roquecor (Table 14), the SF and/or SC of 'follow' present a root sieg-which appears to be a hybrid of N-pattern sièg- and etymological /e/.

In Cancon (47.12) and Siguer (09.22), by contrast, it is the root of the 'N-pattern complement' (defined here as a metamorphome consisting of arrhizotonic reflexes of infectum forms; chiefly the 1PL and 2PL present indicative forms, and all imperfective indicative forms) which is spread to the SF and/or SC: derbreplaces etymological durb-.

\begin{tabular}{|c|c|c|c|c|c|c|c|}
\hline & PRS.IND & IMPF.IND & PRS.SBJV & PRET & IMPF.SBJV & SF & $\mathrm{SC}$ \\
\hline dièrber & dièrb & dièrbiá & dièrba & durbisquèc & durbisquèssa & dièrbirà & durbi(r)iá \\
\hline 'djer $\beta \mathrm{e}$ & djesp & djes'ßjo & 'djer $\beta o$ & dyr $\beta i^{\prime}$ skek & dyг $\beta i^{\prime}$ skeso & $\operatorname{dj\varepsilon \varsigma } \beta i^{\prime}$ га & dys $\beta i^{\prime} j o$ \\
\hline 'open' & durbís & durbissiá & durbisca & & dièrbèssa & durbirà & \\
\hline 31.10 & $\mathrm{dys}^{\prime} \beta$ is & dyr $\beta i^{\prime}$ sjo & dys'ßisko & & $\operatorname{dj} \varepsilon \mathrm{s}^{\prime} \beta \varepsilon \mathrm{so}$ & dyг $\beta i^{\prime} r a$ & \\
\hline sièguer & sièc & sieguiá, & siègua ${ }^{26}$ & sieguisquèc & seguisquèssa & sieguerà & seirá \\
\hline 'sjege & sjek & siegá, & 'sjego & sjegis'kek & segis'keso & sjege'ra & sei'ro \\
\hline 'follow' & & siguiá & & & & & \\
\hline 09.10 & & sje'gjo, & & & & & \\
\hline & & sje'go, & & & & & \\
\hline & & si'gjo & & & & & \\
\hline derbir & dèrb & derbiá & dèrba & durbíc & durbís & durbirà & durbirá ${ }^{27}$ \\
\hline $\operatorname{der}^{\prime} \beta \mathrm{i}$ & $\mathrm{d} \varepsilon \mathrm{sp}$ & der'ßjo & 'd $\varepsilon r \beta o$ & dys' $\beta$ ik & $\mathrm{dyc}^{\prime} \beta$ is & dyг $\beta i^{\prime}$ га & dyг $\beta i^{\prime} г$ \\
\hline 'open' & & & & & & derbirà & \\
\hline 09.22 & & & & & & $\operatorname{der} \beta \mathrm{i}^{\prime} \mathbf{a}$ & \\
\hline durbir & dèrb & dèrbiá & dèrbe & derbi(gu)èt & durbi(gu)èsse & derbirà & derbi(r)iá, \\
\hline $\mathrm{dyc}^{\prime} \beta \mathrm{i}$ & $\mathrm{d} \varepsilon \Gamma$ & $\mathrm{d} \varepsilon \mathrm{c}^{\prime} \beta \mathrm{j} \curvearrowright$ & 'des $\beta \mathrm{e}$ & $\operatorname{der} \beta i^{\prime} \varepsilon t$ & dyヶ $\beta \mathrm{i}^{\prime} \varepsilon s e$ & $\operatorname{der} \beta \mathrm{i}^{\prime}$ га & durbi(r)iá \\
\hline 'open' & & & & & & & $\operatorname{der} \beta \mathrm{i}^{\prime} \mathrm{j} \supset$ \\
\hline 47.12 & & & & & & & dys $\beta \mathrm{i}^{\prime} \mathrm{j} о$ \\
\hline
\end{tabular}

Table 15. Asymmetry by partial or indirect analogy with an N-pattern or N-pattern complement root.

\subsection{Influence of a separate lexeme}

The reflex of RECIPERE is highly susceptible, across the Occitan-speaking area, to analogical remodelling (Ronjat 1932:225) on other lexemes. In Garidech (31.11), Blanquefort (47.11), Laparade (47.21), Allez-etCaseneuve (47.30) and Bioule (82.13), there is alternation within the paradigm between a root receb-/rese $\beta /$ and a root receu-/resew/ (Table 15). The etymological Fuèc forms are most plausibly those with the stem

\footnotetext{
${ }^{25}$ Note that varieties of Occitan in this area commonly present an augment -isc- in the reflexes of Latin perfective forms, even for verbs which lack any augment in the reflexes of imperfective forms.

26 The informant also accepted the form seguisca suggested by the fieldworker.

${ }^{27}$ The informant accepted the fieldworker's suggestion of derbirá as possible, but did not produce it, repeating durbirá.
} 
Preprint of: Esher, Louise. 2015. Formal asymmetries between the Romance synthetic future and conditional in the Occitan varieties of the Western Languedoc. Transactions of the Philological Society 113(2). 249-270.

receb(r)-, as the expected reflex of intervocalic -PR- (including cases in which this cluster results from syncope of intertonic -E-), is $/ \mathrm{br} />/ \beta r /$ (cf. OPERA > òbra; Ronjat 1932:223, Allières 2005:47). However, in all five varieties, SAPERE HABET, HABEBAT > saurà, sauriá (a common model for analogy affecting 'receive'), probably due to analogy with HABERE HABET, HABEBAT > aurà, auriá; and indeed the SF and $\mathrm{SC}$ of other verbs with root-final labials all present the expected historical developments -BR- > /Wr/ or UR- > /wr/ in the SF and SC, e.g. escriurà 'write.SF.3sg', deurà 'have to.SF.3sg', viurà 'live.SF.3sg', beurà 'drink.SF.3sg'. By analogy with these other lexemes, the root receu- is spread into Fuèc, tending to propagate into the SC first and thence into the SF.

\begin{tabular}{|c|c|c|c|c|c|c|c|}
\hline lexeme & PRS.IND & IMPF.IND & PRS.SBJV & PRET & IMPF.SBJV & SF & SC \\
\hline $\begin{array}{l}\text { recèber } \\
47.21\end{array}$ & recèt & recebiá & recèbe & recebèt & recebèsse & receurà & recebriá \\
\hline $\begin{array}{l}\text { recèure } \\
47.11\end{array}$ & $\begin{array}{l}\text { recèp, } \\
\text { recèu }\end{array}$ & recebiá & recèbe & receuèt & receuès & recebrà & receuriá \\
\hline $\begin{array}{l}\text { recèbre } \\
47.30\end{array}$ & recèt & recebiá & recèbe & recebèt & recebèsse & recebrà & receu(r)iá \\
\hline $\begin{array}{l}\text { receure } \\
31.11 \\
\end{array}$ & receu & recebiá & recépie & recepièt & recepièssa & $\begin{array}{l}\text { recebrà } \\
\text { receurà }\end{array}$ & receurá \\
\hline $\begin{array}{l}\text { recèbre } \\
82.13\end{array}$ & recep & recebiá & recèbe & recebèt & recebès & $\begin{array}{l}\text { recebrà } \\
\text { (receurà, } \\
\text { 4e fois) }\end{array}$ & receuriá \\
\hline
\end{tabular}

Table 16. Asymmetry by morphological analogy with other lexemes, in reflexes of RECIPERE 'receive'.

In a different set of five varieties, influence from the reflex of SAPERE creates asymmetry between receurand reçaur- (Table 16). In the the more northerly varieties of Marnac (24.30) and Orniac (46.30), the stem vowel $/ \mathrm{a} /$ introduced from saur- has undergone phonologically regular backing and raising to $/ \mathrm{s} /{ }^{28}$, whereas in the more southerly varieties of Appelle (81.22), Castelnau-de-Lévis (81.04) and Montgaillard-Lauragais (31.31), this phonological process does not apply. The lack of overall directionality in these examples, the coexistence of both variants within the SF at Montgaillard-Lauragais and Castelnau-de-Lévis, and the many varieties across the ALLOc survey area in which reçaur- is found symmetrically in both the SF and SC, all suggest a change in progress. It is worth noting that this study found no examples of asymmetry for the reflex of SAPERE, other than r-less SC forms.

${ }^{28}$ This process is common in northern varieties of Occitan. In Souceyrac (46.13) and Jouels (12.22), both SF and SC present only reçaur-, but only the SF stem shows evidence of backing and raising. These attestations of asymmetry have been omitted as purely due to phonological variation rather than morphological analogy. 
Preprint of: Esher, Louise. 2015. Formal asymmetries between the Romance synthetic future and conditional in the Occitan varieties of the Western Languedoc. Transactions of the Philological Society 113(2). 249-270.

\begin{tabular}{|c|c|c|c|c|c|c|c|}
\hline & PRS.IND & IMPF.IND & PRS.SBJV & PRET & IMPF.SBJV & SF & SC \\
\hline $\begin{array}{l}\text { reçaure } \\
\text { Re'sawre } \\
24.30\end{array}$ & $\begin{array}{l}\text { reçau } \\
\text { Re'saw }\end{array}$ & $\begin{array}{l}\text { reçabiá } \\
\text { Reso'ßjo }\end{array}$ & $\begin{array}{l}\text { reçatge } \\
\mathrm{Re}^{\prime} \text { sae }\end{array}$ & $\begin{array}{l}\text { reçatgèt } \\
\text { Reso'E }\end{array}$ & $\begin{array}{l}\text { reçatgès } \\
\text { Reso'c }\end{array}$ & $\begin{array}{l}\text { receurà } \\
\text { Resew'ro }\end{array}$ & $\begin{array}{l}\text { reçauriá } \\
\text { Resow'rjo }\end{array}$ \\
\hline $\begin{array}{l}\text { reçaber } \\
\text { Reso'ße } \\
46.30\end{array}$ & $\begin{array}{l}\text { reçau } \\
\mathrm{Re}^{\prime} \text { Jaw }\end{array}$ & $\begin{array}{l}\text { reçabiá } \\
\text { Re } \mathrm{o}^{\prime} \beta \text { jo }\end{array}$ & $\begin{array}{l}\text { reçatge } \\
\mathrm{Re}^{\prime} \text { fatse }\end{array}$ & $\begin{array}{l}\text { reçatgèt } \\
\text { Re } \mathrm{o}^{\prime} \text { tset }\end{array}$ & $\begin{array}{l}\text { reçatgès } \\
\text { Re`o'tses }\end{array}$ & $\begin{array}{l}\text { receurà } \\
\text { Re eew'ro }\end{array}$ & $\begin{array}{l}\text { reçauriá } \\
\text { Re`ow'rjo }\end{array}$ \\
\hline $\begin{array}{l}\text { recebre } \\
\text { Re'seßre } \\
31.31\end{array}$ & $\begin{array}{l}\text { receu } \\
\text { Re'sew }^{-}\end{array}$ & $\begin{array}{l}\text { recebiá } \\
\text { Rese' } \beta \text { jo }\end{array}$ & $\begin{array}{l}\text { recebe } \\
\mathrm{Re}^{\prime} \mathrm{se} \beta \mathrm{e}\end{array}$ & 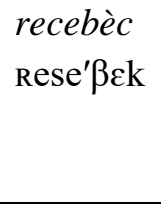 & $\begin{array}{l}\text { recebèssa } \\
\text { Rese' } \beta \varepsilon s っ\end{array}$ & $\begin{array}{l}\text { (reçaurà), } \\
\text { receurà } \\
\text { Resaw'ra, } \\
\text { Resew'ra }\end{array}$ & $\begin{array}{l}\text { receuriá } \\
\text { Resew'ro }\end{array}$ \\
\hline $\begin{array}{l}\text { reçaure } \\
\text { Re'sawre } \\
81.22\end{array}$ & $\begin{array}{l}r e c ̧ a u \\
\text { Re'saw }\end{array}$ & 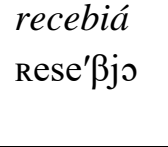 & $\begin{array}{l}\text { reçapie } \\
\mathrm{Re}^{\prime} \text { sapje }\end{array}$ & $\begin{array}{l}\text { reçapièt } \\
\text { Resa'pjet }\end{array}$ & $\begin{array}{l}\text { reçapièssa } \\
\text { Resa'pjeso }\end{array}$ & $\begin{array}{l}\text { reçaurà } \\
\text { Resaw'ra }\end{array}$ & $\begin{array}{l}\text { reçeuriá } \\
\text { Resew'ro }\end{array}$ \\
\hline $\begin{array}{l}\text { reçaure } \\
\text { Re'sawre } \\
81.04\end{array}$ & $\begin{array}{l}\text { reçau } \\
\text { Re'saw }\end{array}$ & $\begin{array}{l}\text { reçabiá } \\
\text { Resa'ßjə }\end{array}$ & $\begin{array}{l}\text { reçapia } \\
\text { Re'sapjo }\end{array}$ & $\begin{array}{l}\text { reçapièt } \\
\text { Resa'pjet }\end{array}$ & $\begin{array}{l}\text { reçapièssa } \\
\text { Resa'pjeso }\end{array}$ & $\begin{array}{l}\text { receurà, } \\
\text { reçaurà } \\
\text { Resew'ra, } \\
\text { Resaw'ra }\end{array}$ & $\begin{array}{l}\text { receurá } \\
\text { Resew'rjo }\end{array}$ \\
\hline
\end{tabular}

Table 17. Asymmetry by morphological analogy with other lexemes, coupled with phonological variation, in reflexes of RECIPERE 'receive'.

\section{$5.4 \quad$ Summary}

Asymmetries which are transparently due to morphological analogy are by far the rarest type. In some cases, such asymmetries result from the extension of another root within the paradigm, while in others, the model of analogy comes from a separate lexeme. Among the striking aspects of such asymmetries is the arbitrary way in which analogy may affect either the SF or the SC: just as, in cases of heteroclite patterns, either the SF or SC of a class IIIb verb may adopt a first-conjugation form, in cases of asymmetry by analogy with other lexemes, either form may undergo remodelling. While the data presented here suggest that the SC may be marginally more likely than the SF to adopt a stem based on the PYTA ${ }^{29}$ root, and the SF to adopt a stem based on the N-pattern ${ }^{30}$ root, these apparent tendencies should be treated with caution. The rarity of asymmetry by analogy means that the sample size is very small, and could easily be skewed; all the more so, as it is notable that examples of N-pattern-influenced SC forms and PYTA-influenced SF forms are also found in these (and other) varieties of Occitan. On the basis of these data, no sound conclusion can be drawn about the possible morphological links between the SF, SC and other morphomes.

${ }^{29}$ See $\$ 5.1$ above.

${ }^{30}$ See $\$ 5.2$ and fn.20 above. 
Preprint of: Esher, Louise. 2015. Formal asymmetries between the Romance synthetic future and conditional in the Occitan varieties of the Western Languedoc. Transactions of the Philological Society 113(2). 249-270.

Yet the arbitrariness of asymmetry by analogy is not necessarily surprising. In cases of asymmetry motivated by phonological form (e.g. asymmetry by metaphony, asymmetry by r-deletion or vocalic asymmetry), there is an obvious phonological contrast between the SF and SC, and the changes which occur target the (slightly more complex) phonological strings found in the SC rather than those found in the SF; thus there are sound phonological reasons for the SC to be more susceptible to change, and the systematicity of innovation occurring preferentially in the $\mathrm{SC}$ is entirely consistent with the processes giving rise to innovation. But in cases of asymmetry by analogy, the asymmetries do not arise in response to a systematic phonological difference. Instead, they instantiate a new, abstract morphological template in which the SF and SC have different stems. This template arises via the phonological changes described above, but the diverse outcomes of the changes, across lexemes and conjugational classes, create a wide variety of models for the formal relationships between the stems found in the SF and SC, and the stems found in other groups of paradigm cells. The lack of significant directionality in the novel asymmetries by analogy reflects the diversity of existing models for paradigms with asymmetry between SF and SC forms..

What does emerge, however, is a correlation between the presence of different types of asymmetry. The geographical distribution of the different types is summarised in Figure 3: over four-fifths of asymmetries which are of recent morphological origin (IIIb/I heteroclisis, analogy with other lexemes, analogy with other roots within the same paradigm) occur in the two-thirds of varieties which already present asymmetry of phonological origin. 
Preprint of: Esher, Louise. 2015. Formal asymmetries between the Romance synthetic future and conditional in the Occitan varieties of the Western Languedoc. Transactions of the Philological Society 113(2). 249-270.

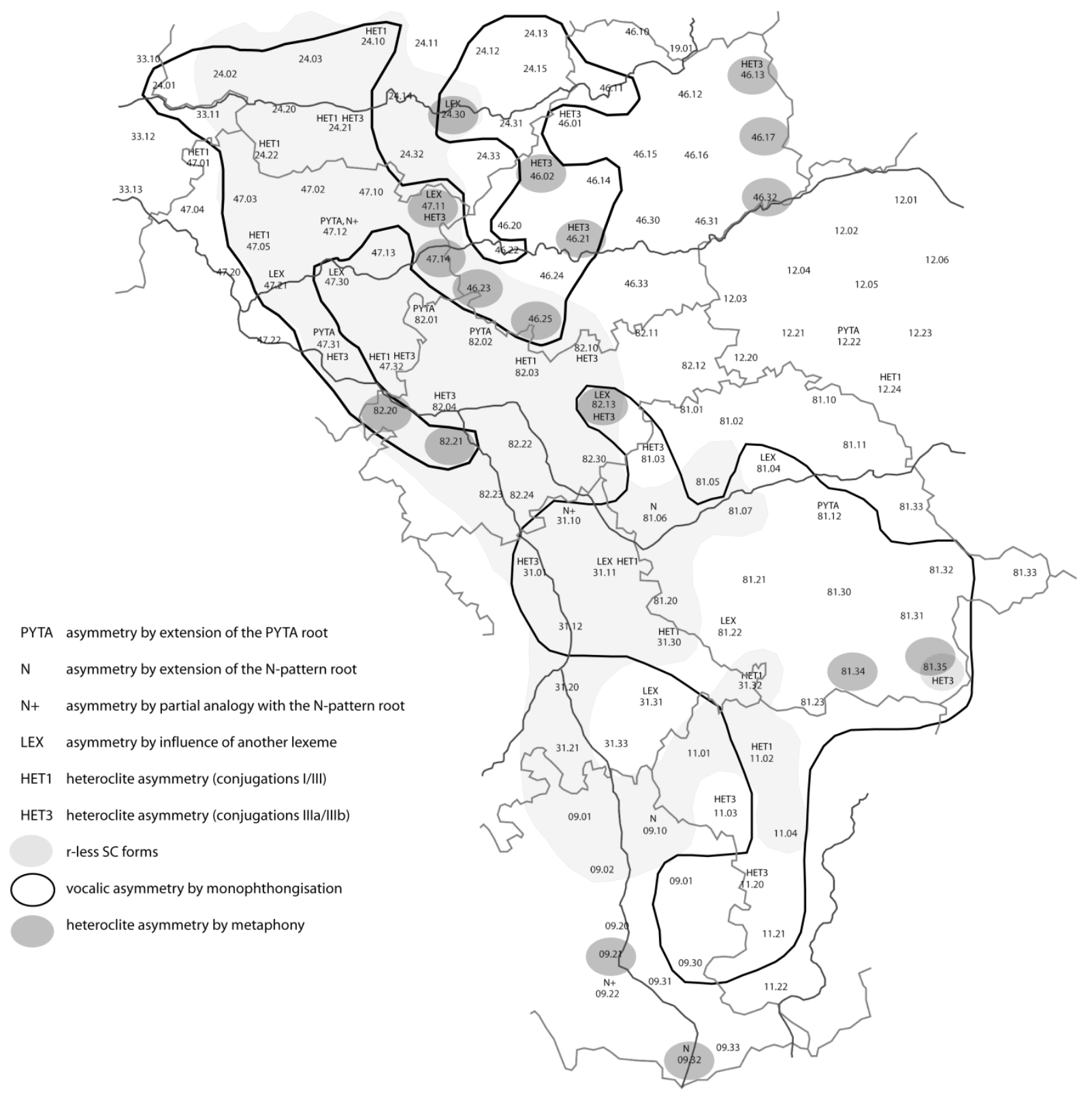

Figure 3. Overall geographical distribution of asymmetries 
Preprint of: Esher, Louise. 2015. Formal asymmetries between the Romance synthetic future and conditional in the Occitan varieties of the Western Languedoc. Transactions of the Philological Society 113(2). 249-270.

\section{DISCUSSION}

The data discussed in this study illustrate the prevalence and typological diversity of stem asymmetry between the Romance synthetic future and conditional in the Occitan varieties of the western Languedoc. Stem asymmetry is shown to be, in many cases, a genuinely morphological phenomenon, arising from two major sources: regular phonological changes, the results of which have plausibly been morphologised to create a novel template for stem distribution differentiating between SF and SC, and morphological analogies based on this novel template.

The existence of asymmetry may appear surprising, both within the Romance context and from the perspective of autonomous morphology. Exceptionless formal identity between SF and SC stems is a widespread pattern in Romance, familiar from the major standard languages and also found in several other varieties of Occitan; while diachronic persistence is a striking feature of familiar metamorphomes such as PYTA and the N-pattern (see e.g. Maiden 2005, 2009a), with which Fuèc shares many properties. Yet the mechanisms by which SF/SC asymmetry in Occitan arises prove to be familiar ones. Asymmetry results from the same principles which have produced the N-, L- and U-pattern ${ }^{31}$ morphomes in Romance (Maiden 2009a, 2011): formal differentiation due to sound change, reanalysed by speakers as a morphological contrast. $^{32}$

Functional motivation, although often adduced as a justification for the formal similarity of SF and SC in Romance, is inadequate to explain the observed distributions. It is probably true that the functional motivation which is often adduced for Fuèc is less robust in Occitan than in French (see Esher 2013 for discussion). However, it is far from clear that the varieties of the western Languedoc show any less functional commonality between SF and SC than Italo-Romance varieties, for which I am not aware of formal asymmetries between SF and SC. In the Languedoc, SF and SC share the values of temporal posteriority, possibility and attenuation, but only the SF expresses conjectural, epistemic modality (Esher 2013), a value occurring only infrequently and in a restricted range of lexemes (Barceló 2004). By contrast, in Italo-Romance, the SC famously does not share the value of temporal posteriority with the SF (Maiden 1996). If functional motivation were the only, or the major, factor determining the formal identity between SF and SC stems, one would expect to find that Fuèc would be at least as coherent in the Occitan varieties discussed here as in Italo-Romance, and probably more so.

The present study instead highlights the role of sound change, coupled with frequency effects. The principles at work can be seen for the initial emergence of the metamorphome Fuèc, which arises due to phonological changes affecting the construction infinitive+'have': the changes maintain identity between

\footnotetext{
${ }^{31}$ The L-pattern comprises all PRS.SBJV forms, plus the PRS.IND.1SG; the U-pattern comprises all PRS.SBJV forms, plus PRS.IND.1SG and PRS.IND.3SG. Though well-represented in Italo- and Ibero-Romance (see Maiden (e.g. 2009a) for discussion), neither survives in the Occitan varieties of the Languedoc.

${ }^{32}$ If this view is correct, one would expect that asymmetry between SF and SC could potentially be found in any Romance variety having undergone sound changes liable to differentiate the SF from the SC, but would not be found outside such varieties.
} 
Preprint of: Esher, Louise. 2015. Formal asymmetries between the Romance synthetic future and conditional in the Occitan varieties of the Western Languedoc. Transactions of the Philological Society 113(2). 249-270.

SF and SC stems, while differentiating these from the infinitive. If changes in stress assignment are taken into account, such differentiation operates in most, if not all, lexemes. As a result, the majority pattern of paradigmatic distribution is for the SF and SC to share a distinctive stem. I suggest that the high type frequency of this pattern within the lexicon increases the likelihood of speakers acquiring and replicating it, since it constitutes a stable, predictable pattern for the distribution of allomorphy within the paradigm.

With regard to the modern ALLOc data, it is striking that the rather scattered and diverse asymmetries due to purely morphological processes occur in areas which already present asymmetries due to phonological processes. The asymmetries of phonological origin are in general commoner and more consistent than the asymmetries of morphological origin, and the geographical correlations observed support the conjecture that phonological asymmetry precedes morphological asymmetry. It is plausible that, where sound changes have created an incidental, context-sensitive disparity between SF and SC forms, this disparity has subsequently been reanalysed by speakers as an inherent contrast of stems. Such reanalysis is facilitated where sound changes apply to a high proportion of lexemes (as in the case of r-deletion). The result is a change in the shape of the metamorphomic templates available in the paradigm. Once a template dissociating the SF from the SC is created, it is available as a model for morphological analogy, opening the way for asymmetries of morphological origin.

On this view, just as the loss of coherence of the set of paradigm cells labelled 'infectum' in Latin is treated from the perspective of the emergence of the N-, L- and U-patterns (Maiden 2009a, 2011), asymmetry within Fuèc is less to be considered the demise of one morphome, as the rise of a new one. 
Preprint of: Esher, Louise. 2015. Formal asymmetries between the Romance synthetic future and conditional in the Occitan varieties of the Western Languedoc. Transactions of the Philological Society 113(2). 249-270.

\section{REFERENCES}

ADAMS, J. N., 1991. 'Some neglected evidence for Latin habeo with infinitive: the order of the constituents', Transactions of the Philological Society 89, 131--196.

ALBRIGHT, ADAM, 2009. 'Modeling analogy as probabilistic grammar', in James P. Blevins \& Juliette Blevins (eds.), Analogy in Grammar, Oxford: OUP, 185--204.

ALIBÈRT, LoÍs, 1976. Gramatica occitana segon los parlars lengadocians, $2^{\text {nd }}$ ed., Montpelhièr: CEO.

ALLANCHE, LOUIS, 1941. Eléments de grammaire du dialecte quercynol des environs de Moissac et de Montauban suivis de proverbes et de dictons, Montauban: Forestié.

ALLIÈRES, JACQUES, 2005. Formation et structure de l'occitan ancien, Villeneuve-sur-Lot: Massourre.

ARONOFF, MARK, 1994. Morphology by Itself: Stems and Inflectional Classes, Cambridge, Mass.: MIT Press.

BACH, XAVIÈR \& ESHER, LOUISE, forthcoming. 'Morphological evidence for the paradigmatic status of infinitives in French and Occitan', in Dag Haug (ed.), Historical Linguistics 2013, Amsterdam: Benjamins.

BARCELÓ, GERARD, 2004. 'Lo(s) futur(s) occitan(s) e la modalitat : elements d'estudi semantic comparatiu', Lingüistica Occitana 2, available online at: http://superlexic.com/revistadoc/wpcontent/uploads/2013/06/Linguistica-Occitana-2-Barcelo.pdf (accessed May 2014).

BOISGONTIER, JACQUES, 1981-86. Atlas linguistique et éthnographique du Languedoc oriental (3 vols.), Paris: CNRS.

BYBeE, JoAn, 2001. Phonology and language use, Cambridge: CUP.

Bybee, JoAn, Perkins, Revere Dale \& PAgliUCA, William, 1994. The evolution of grammar: tense, aspect and modality in the languages of the world, Chicago: University of Chicago Press.

CAMPS, Christian, 1985. Atlas linguistique du Biterrois, Toulouse: Institut d'Estudis Occitans.

DELEDAR, JÒRDI, 2006. Les Parlers couserannais, Villeneuve-sur-Lot: Massourre. ${ }^{33}$

ESHER, LOUISE, 2013. 'Future and conditional in Occitan: a non-canonical morphome?', in Silvio Cruschina, Martin Maiden \& John Charles Smith (eds.), The Boundaries of Pure Morphology: Diachronic and Synchronic Perspectives, Oxford: OUP, 95--115.

FLeISCHMAn, SUZANNE, 1982. The Future in Thought and Language, Cambridge: CUP.

EYGUN, JEAN, 1999. Le texte réligieux d'expression occitane de 1600 à 1850, Ph.D dissertation, University of Montpellier.

Kelly, ReIne Cardaillac, 1973. A Descriptive Analysis of Gascon, The Hague \& Paris: Mouton.

LANLY, ANDRÉ, 1971. 'Sur des formes occitanes de conditionnel sans -r-', in Irénée Cluzel \& François Pirot (eds.), Mélanges de philologie romane dédiés à la mémoire de Jean Boutière (1899-1967), Liège: Soledi.

LAVAlADE, YVES, 1987. La Conjugaison occitane (Limousin), Limoges: IEO/La Clau Lemosina.

LIGNIÈRES, MARCEL, 1951. Grammaire pratique de langue d'oc, avec vocabulaire, Béziers: Sudiep.

MAIDEN, MARTIN, 1991. Interactive morphonology: metaphony in Italy, London: Routledge.

${ }^{33}$ Attributed in error to Jacques Allières, whose name appears on the cover and title page. 
Preprint of: Esher, Louise. 2015. Formal asymmetries between the Romance synthetic future and conditional in the Occitan varieties of the Western Languedoc. Transactions of the Philological Society 113(2). 249-270.

MAIDEN, MARTIN, 1996. "Ipotesi sulle origini del condizionale analitico come "futuro del passato" in italiano', in Paola Benincà, Gugliemo Cinque, Tullio De Mauro \& Nigel Vincent (eds.) L'italiano nel tempo. Studi di grammatica offerti a Giulio Lepschy. Rome: Bulzoni. 149--173.

MAIDEN, MARTIN, 2005. 'Morphological autonomy and diachrony', Yearbook of Morphology 2004, 137-175.

MAIDEN, MARTIN, 2009a. 'From pure phonology to pure morphology. The reshaping of the Romance verb', Recherches de linguistique de Vincennes 38, 45--82.

MAIDEN, MARTIN, 2009b. 'Where does heteroclisis come from? Evidence from Romanian dialects', Morphology 19, 59-86.

MAIDEN, MARTIN, 2011. 'Morphophonological innovation', in Martin Maiden, John Charles Smith \& Adam Ledgeway (eds.), The Cambridge History of the Romance Languages, vol. 1, Cambridge: CUP, 216--67.

MAiden, MARTin \& SMith, John Charles, 2014. 'Glimpsing the future: Some rare anomalies in the history of the Italo-Romance and Gallo-Romance future and conditional stem, and what they suggest about paradigm structure', in Paola Benincà, Adam Ledgeway \& Nigel Vincent (eds.), Diachrony and Dialects: Grammatical Change in the Dialects of Italy, Oxford: OUP, 116-30.

RAVIER, XAVIER, 1971-93. Atlas linguistique et éthnographique du Languedoc occidental (4 vols.), Paris: CNRS.

ReYdy, JEAN-PIERRE, 2008. Notre Occitan. Le dialecte du Périgord-Limousin parlé dans le Parc naturel régional, Bassac: IEO-Lemosin.

RONJAT, JULES, 1932. Grammaire istorique des parlers provençaux modernes, vol. 2, Montpellier: Société des Langues Romanes.

RONJAT, JULES, 1937. Grammaire istorique des parlers provençaux modernes, vol. 3, Montpellier: Société des Langues Romanes.

ROUND, ERICH, in prep. 'Rhizomorphomes, meromorphomes and metamorphomes'.

SÉGUY, JEAN, 1954-73. Atlas linguistique et éthnographique de la Gascogne (6 vols.), Paris: CNRS.

SÉGUY, JEAN, 1973. 'Les Atlas linguistiques de la France par régions', Langue française 18, 65--90.

SICRE, PAUL, 1909. Eléments de grammaire du dialecte de Foix, Foix: Société Ariégeoise.

STUMP, GREGORY, 2006. 'Heteroclisis and paradigm linkage', Language 82, 279--322.

WHEELER, MAX, 2011. 'The Evolution of a Morphome in Catalan Verb Inflection', in Silvio Cruschina, Martin Maiden \& John Charles Smith (eds.), The Boundaries of Pure Morphology: Diachronic and Synchronic Perspectives, Oxford: OUP, 183--209. 